\title{
Characterisation of a murine model of the late asthmatic response
}

\author{
Katie Baker ${ }^{1}$, Kristof Raemdonck ${ }^{2,3}$, Robert J. Snelgrove ${ }^{4}$, Maria G. Belvisi ${ }^{1,5}$ and Mark A. Birrell ${ }^{1,5^{*}}$
}

\begin{abstract}
Background: The incidence of asthma is increasing at an alarming rate. While the current available therapies are effective, there are associated side effects and they fail to adequately control symptoms in all patient subsets. In the search to understand disease pathogenesis and find effective therapies hypotheses are often tested in animal models before progressing into clinical studies. However, current dogma is that animal model data is often not predictive of clinical outcome. One possible reason for this is the end points measured such as antigen-challenge induced late asthmatic response (LAR) is often used in early clinical development, but seldom in animal model systems. As the mouse is typically selected as preferred species for pre-clinical models, we wanted to characterise and probe the validity of a murine model exhibiting an allergen induced LAR.

Methods: C57BL/6 mice were sensitised with antigen and subsequently topically challenged with the same antigen. The role of Alum ${ }^{\mathrm{TM}}$ adjuvant, glucocorticoid, long acting muscarinic receptor antagonist (LAMA), TRPA1, $\mathrm{CD}^{+}$and $\mathrm{CD} 8^{+} \mathrm{T}$ cells, B cells, Mast cells and IgE were determined in the LAR using genetically modified mice and a range of pharmacological tools.

Results: Our data showed that unlike other features of asthma (e.g. cellular inflammation, elevated IgE levels and airway hyper-reactivity (AHR) the LAR required Alum ${ }^{T M}$ adjuvant. Furthermore, the LAR appeared to be sensitive to glucocorticoid and required CD4 ${ }^{+} T$ cells. Unlike in other species studied, the LAR was not sensitive to LAMA treatment nor required the TRPA1 ion channel, suggesting that airway sensory nerves are not involved in the LAR in this species. Furthermore, the data suggested that $\mathrm{CD} 8^{+} \mathrm{T}$ cells and the mast cell—B-cell - IgE axis appear to be protective in this murine model.

Conclusion: Together we can conclude that this model does feature steroid sensitive, CD4 ${ }^{+} \mathrm{T}$ cell dependent, allergen induced LAR. However, collectively our data questions the validity of using the murine pre-clinical model of LAR in the assessment of future asthma therapies.
\end{abstract}

\section{Background}

Asthma is defined as a heterogeneous disease, usually characterized by chronic airway inflammation. Patients generally present with a history of respiratory symptoms such as wheeze, shortness of breath, chest tightness and cough that vary over time and in intensity, together with variable expiratory airflow limitation [1-4]. It affects approximately 300 million people worldwide and the World Health Organisation estimates asthma to

\footnotetext{
* Correspondence: m.birrell@imperial.ac.uk

${ }^{1}$ Respiratory Pharmacology, Airway Disease Section, National Heart and Lung Institute, Faculty of Medicine, Imperial College London, Exhibition Road, London SW7 2AZ, UK

${ }^{5}$ Asthma UK Centre in Allergic Mechanisms of Asthma, Imperial College London, London, UK

Full list of author information is available at the end of the article
}

represent $1 \%$ of the total global disease burden $[5,6]$. The prevalence of asthma is still on the rise and escalating healthcare costs are making it a global health concern [3, 5-8] Asthma is characterised by airway hyperresponsiveness (AHR), reversible bronchoconstriction, airway remodelling events and chronic inflammation. A wide range of environmental and endogenous stimuli have been shown to trigger asthma symptoms including; allergens, exercise and cold air $[9,10]$. Recent attempts at phenotyping asthma have adopted cluster based approaches whereby patients are grouped according to a multitude of possible features such as age of onset, atopic status, severity of airways obstruction and medication requirements. Atopic asthma is associated with allergy (elevated levels of allergen specific IgE) and 
atopic sensitisation has been implied as an important determinant in the development of asthma.

Allergen inhalation challenge in patients with mild asthma is considered to be a useful model for understanding the mechanisms involved in the pathophysiology of asthma and also to be predictive of therapeutic utility. Allergen inhalation challenge results in a biphasic bronchoconstrictor response, an early asthmatic response (EAR) and a late asthmatic response (LAR) [11, 12]. The EAR usually takes place within $1 \mathrm{~h}$ following aeroallergen exposure and is associated with the allergen causing cross-linking of the IgE on mast cells leading to mast cell degranulation and the release of inflammatory mediators such as histamine and cysteinyl-leukotrienes [13-15]. The Late Asthmatic Response (LAR) refers to a more prolonged bronchoconstriction event taking place approximately $3-8 \mathrm{~h}$ following contact with aeroallergen $[11,12]$, however, the aetiology behind the response is less well understood than that of the EAR. Studies so far exploring this particular feature of asthma have concluded that it is likely that the LAR is at least in part driven by inflammation. This conclusion is largely based on the fact that the response is accompanied by cellular inflammatory influx into the lung along with the demonstration that steroid treatment impacts on the response [16, 17]. Others have suggested alternative mechanisms behind the LAR such as a possible role for airway sensory nerves [18].

Pre-clinical animal models are used in the drug discovery process to understand disease pathogenesis and to test the utility of potential therapeutics [12]. The mouse is being increasingly utilised in pre-clinical asthma models due to the availability of new genetically modified strains [19-21]. However, it is increasingly being reported that data obtained from animal models is not predictive of clinical therapeutic outcome [22, 23]. One possible reason for this could be that the murine models most frequently used exhibit a number of asthmatic endpoints such as AHR, airway inflammation and airway remodelling events; but do not always demonstrate the same endpoints as those used in early clinical development such as allergen induced LAR. Very few publications have described a murine LAR and the nature of the response has not previously been investigated. Therefore, the purpose of this investigation was to characterise an OVA-driven mouse model of the LAR including probing the role of sensory nerves and key allergic effector cells, and the requirement for adjuvant.

\section{Methods}

\section{Animals}

All experimental protocols were approved by a local ethical review process and strictly adhered to the Animals (Scientific Procedures) Act 1986 UK Home Office guidelines and performed according to the
ARRIVE guidelines. All animals were housed in individually ventilated cages (IVC) and a 12-h light-dark cycle maintained. Prior to and during experimental periods, food and water was supplied ad libitum. C57BL/6 wildtype (Harlan, UK), mast-cell knockout [KitW-sh] (Jackson Laboratories Ltd, USA), B-cell knockout (Swiss Immunological Mouse Repository), Trpa1 knockout (Jackson Laboratories Ltd, USA and Prof. Peter Zygmunt, Sweden - originally developed by Prof David Julius USA), CD4 knockout (Swiss Immunological Mouse Repository), CD8 knockout (Swiss Immunological Mouse Repository) and IgE knockout (Swiss Immunological Mouse Repository) male mice aged 8-12 weeks were bred in house. In the experiments detailed below a randomization procedure used to allocate the animals to various groups.

\section{The OVA driven mouse model of LAR}

Male mice (20-25 g) were sensitised with OVA in Alum $^{\mathrm{TM}}(50 \mu \mathrm{g}$ per mouse, $500 \mu \mathrm{l}$, i.p. $)$ or vehicle (Alum $^{\mathrm{TM}}$ diluted 1:1 with saline, $500 \mu \mathrm{l}$, i.p) on days 0 and 14 in their home cage. On day 28, mice were given a single intra-tracheal (i.t.) dose of OVA (2\% OVA, $25 \mu \mathrm{l})$ as described [18, 24]. For the i.t. dosing, mice were placed in a Perspex chamber connected to an anaesthetic machine (Bowring Medical Engineering Ltd, Witney, UK) and exposed to $4 \%$ isoflurane in $0.5 \%$ oxygen until sufficiently anaesthetised. Mice were dosed into the trachea using a dosing gavage and then monitored until fully recovered. Immediately following recovery from i.t. dosing, mice were placed in WBP chambers (Buxco Electronics, USA) and pressure changes continuously recorded by BuxcoFinepointe Software (Buxco Electronics, USA). The average Penh was recorded at $10 \mathrm{~min}$ intervals for a total duration of $12 \mathrm{~h}$ and was used for analysis.

In order to assess the importance of Alum ${ }^{\mathrm{TM}}$ adjuvant within this model, the protocol was adapted by sensitizing different groups with and without Alum ${ }^{\mathrm{TM}}$ adjuvant. The effect of a clinically used glucocorticosteroid, Budesonide (given at an effective supra-maximal dose of $3 \mathrm{mg} / \mathrm{kg}$ at $10 \mathrm{ml} / \mathrm{kg}$, p.o., [18, 25-29]) or vehicle $(0.5 \%$ methylcellulose, $0.2 \%$ Tween 80 in water) dosed $60 \mathrm{~min}$ before allergen challenge, was assessed. The effect of LAMAs was tested by dosing mice with Tiotropium (0.001 $\mathrm{mg} / \mathrm{kg}$ i.t.), Glycopyrrolate $(0.01 \mathrm{mg} / \mathrm{kg}$ i.t.) or vehicle $(0.5 \%$ ethanol in saline, $50 \mu \mathrm{l}$ i.n.) one hour before allergen challenge. Effective doses were chosen based on dose-response experiments in OVA driven mouse models of AHR (see next section for methodology). Immediately following recovery from allergen challenge, mice were placed in WBP chambers and Penh recorded for $12 \mathrm{~h}$ as previously detailed $[18,30]$. The role of TRPA1, CD4 ${ }^{+}$cells, $\mathrm{CD} 8^{+}$cells, mast cells, B- 
cells and IgE was investigated by applying the relevant knockout mice to the model and comparing responses to that of wildtype mice.

\section{The OVA driven mouse model of AHR}

Mice were dosed $50 \mathrm{ul}$ i.n. with tiotropium (1 $\mu \mathrm{g}$ $0.1 \mathrm{mg} / \mathrm{kg})$, glycopryrrolate $(0.01-10 \mathrm{mg} / \mathrm{kg})$ or vehicle (saline, i.n.) $240 \mathrm{~min}$ before challenge. Mice were then placed in the Penh chambers and allowed to acclimatise for $2 \mathrm{~min}$ followed by a 2-min recording of the baseline. They were then exposed to saline and methacholine (2$32 \mathrm{mg} / \mathrm{ml}$, every $10 \mathrm{mins})$. Whole body plethysmography (WBP; Penh) was used to assess changes in airway tone. Penh was recorded for $10 \mathrm{~min}$ between doses. Animals were culled following the experiment.

\section{Measurement of plasma IgE}

Animals were euthanised via overdose with Sodium Pentobarbitone (200 mg/kg i.p.). Blood was attained via cardiac puncture with a heparinised syringe. Samples were then centrifuged (1398 g, $10 \mathrm{~min}, 4{ }^{\circ} \mathrm{C}$ ) and the plasma supernatant transferred to eppendorfs and stored at $-20^{\circ}$ $\mathrm{C}$ until subsequent analysis. The level of plasma IgE was used as a marker of allergic sensitisation and measured using Enzyme Linked Immunosorbant Assay (ELISA). Total and allergen specific IgE levels were measured using BD OptEIATM set for mouse immunoglobulin E (BD Biosciences, Oxford, UK) in accordance with the manufacturer's instructions (see Additional file 1).

\section{Bronchoalveolar lavage fluid (BALF)}

The trachea was exposed via blunt dissection and cannulated. A syringe was used to introduce RPMI media (Life Technologies) into the lungs for $30 \mathrm{~s}$, before being withdrawn. $0.3 \mathrm{mls}$ was introduced 3 times. The samples were then pooled to give 1 sample per animal, before being prepared for total and differential cell counts. The total leukocyte cell counts in BAL fluid were attained using a Sysmex XP-300 automated cell counter (Sysmex Ltd., UK). Slides for differential cell counts were prepared using $100 \mu \mathrm{l}$ BAL fluid in a cytospin (807 g, $5 \mathrm{~min}$, room temperature, low acceleration) (Shandon, Runcorn, UK). Slides were stained using a Hema-tek 2000 automated slide stainer (Ames Co., Elkhart, USA) using ACCUSTAIN $^{\circ}$ modified Wright-Giemsa stain (Sigma). Slides were analysed under light microscopy at $\times 40$ magnification by an observer blinded to the specimen identities. Differential counts were completed on 200 cells per slide using standard morphological criteria. The percentage of macrophages/monocytes, neutrophils, eosinophils and lymphocytes were calculated. Macrophages and monocytes were counted as one group. Other cell types such as epithelial cells and red blood cells were ignored.

\section{Flow cytometry}

Flow cytometry was used to validate the lung tissue cell populations within the genetically modified and wildtype mice. Naïve animals were culled via overdose with Sodium Pentobarbitone $(200 \mathrm{mg} / \mathrm{kg}$ i.p.). The systemic circulation was then perfused. The lungs were removed, weighed and finely chopped using a Mcllwain tissue chopper (Campden Instruments Ltd, UK) and transferred to $1 \mathrm{ml}$ Roswell Park Memorial Institute media (RPMI)/Penicillin-Streptomycin. This was then added to 4mls RPMI supplemented with 10\% Foetal Bovine Serum (FBS), collagenase $(1 \mathrm{mg} / \mathrm{ml})$ and DNase $(25 \mu \mathrm{g} /$ $\mathrm{ml}$ ) and incubated in a water bath with gentle agitation for $1 \mathrm{~h}$ at $37{ }^{\circ} \mathrm{C}$. Following this, samples were filtered using a $70 \mu \mathrm{m}$ mesh sieve. The samples then underwent two rounds of centrifugation at $807 \mathrm{~g}$, discarding the supernatant and re-suspending the pellet in $10 \mathrm{mls}$ RPMI (supplemented as previous) each time. For each sample, a total leukocyte cell count was performed using a Sysmex XP-300 cell counter (Sysmex Ltd., UK). Cells were stained for surface markers as detailed in Snelgrove et al., 2008 [31]. Cell types were characterised by their forward and side scatter profiles and by their specific phenotypes (See Table 1). Unstained controls were used to account for the auto-fluorescence of the samples and the Photomultiplier tube (PMT) gains set accordingly. Single stained controls were used to account for spectral overlap and the flow cytometer compensations set accordingly. Gates to assess positive and negative staining were set using standard fluorescence minus one (FMO) controls for each monoclonal antibody conjugate.

Table 1 Outlining surface marker antigens and relevant conjugated monoclonal antibodies used to identify various cell populations

\begin{tabular}{|c|c|c|}
\hline Cell Type & $\begin{array}{l}\text { Surface marker } \\
\text { Phenotype }\end{array}$ & $\begin{array}{l}\text { Monoclonal Antibody } \\
\text { Conjugate }\end{array}$ \\
\hline B-cells & $\mathrm{CD}_{19}{ }^{+}$ & Rat anti-mouse CD19 (FITC) \\
\hline CD4 ${ }^{+}$T-cells & $\mathrm{CD}^{+}$ & CD4 (PerCP) \\
\hline $\mathrm{CD}^{+}{ }^{\mathrm{T}}$-cells & $\mathrm{CD}^{+}$ & CD8 (APC) \\
\hline Neutrophils & $\begin{array}{l}\text { Ly- } 6 G^{\text {high }} \\
\text { CD11 b bigh } \\
\text { CD11 } c^{\text {low }} \\
\text { F4/80 } 40^{\text {low }}\end{array}$ & $\begin{array}{l}\text { Ly6G (FITC) } \\
\text { CD11 b (PerCP) } \\
\text { CD11c (APC) } \\
\text { F4/80 (PE) }\end{array}$ \\
\hline Eosinophils & $\begin{array}{l}\text { CD11b bigh } \\
\text { CD11 } c^{\text {low }} \\
\text { Ly6Glow } \\
\text { SiglecF }\end{array}$ & $\begin{array}{l}\text { CD11b (PerCP) } \\
\text { CD11c (APC) } \\
\text { Ly6G (FITC) } \\
\text { SiglecF (PE) }\end{array}$ \\
\hline \multirow[t]{2}{*}{ Alveolar Macrophages } & $\begin{array}{l}\text { CD11blow- } \\
\text { intermediate }\end{array}$ & \multirow{2}{*}{$\begin{array}{l}\text { CD11b (PerCP) } \\
\text { CD11c (APC) } \\
\text { F4/80 (PE) } \\
\text { Ly6G (FITC) }\end{array}$} \\
\hline & $\begin{array}{l}\text { CD11 } C^{\text {high }} \\
\text { F4/80 } \\
\text { Ly-6G low }\end{array}$ & \\
\hline $\begin{array}{l}\text { Inflammatory monocytes/ } \\
\text { tissue macrophages }\end{array}$ & $\begin{array}{l}\text { CD11 } b^{\text {high }} \\
\text { CD11 } c^{\text {low }} \\
\text { F } 4 / 80^{\text {high }}\end{array}$ & $\begin{array}{l}\text { CD11b (PerCP) } \\
\text { CD11c (APC) } \\
\text { F4/80 (PE) }\end{array}$ \\
\hline
\end{tabular}




\section{Histology}

Histology was used to validate the lung tissue mast cell populations within the genetically modified and wildtype mice. Mast cells were identified using a standard Toluidine blue histological stain. Mice were culled via overdose with sodium Pentobarbitone and the systemic circulation perfused as described in the previous section. The trachea was then cannulated and the lungs superfused with formalin before being placed in formalin for $24 \mathrm{~h}$. Following this, they were transferred into $70 \%$ ethanol until paraffin wax embedding and slicing could take place. The paraffin embedded lung samples were cut into $4 \mu \mathrm{m}$ sections. The sections were stained using a standard Toluidine Blue and eosin counterstain protocol as in Yagil et al. (2012) [32]. Briefly, the lung sections were dewaxed using Histochoice clearing agent (Sigma, UK) and rehydrated in a series of ethanol dilutions $(100,90,70 \%)$. The slices were then washed in deionised water and stained in $0.1 \%$ Toluidine Blue (Sigma, UK) for $5 \mathrm{~min}$. Sections were then washed in distilled water before counterstaining with Eosin-Phloxine solution (Sigma, UK) for $1 \mathrm{~min}$. A final wash in distilled water then took place before the slices were dehydrated using a series of ethanol dilutions (70, 90, 100\%). The slices were left to dry at room temperature and mounted onto glass slides [32]. The stained sections were analysed under light microscopy at $\times 40$ magnification, the observer blinded to the specimen identities. The numbers of mast cells per slide (3 slides per lung sample) were counted.

\section{Compounds and materials}

Isoflurane was from Abbott Laboratories (UK). BD OptEIATM set for mouse immunoglobulin E was from BD Biosciences (US). Medical Oxygen was from BOC Industrial Gases (UK). FBS and Fixable near-IR dead cell stain kit for 633/635 nm excitation was from Invitrogen (UK). Collagenase and DNase was from Roche Diagnostics (Germany). Alum $^{\text {TM }}$ was from ThermoFisher Scientific (UK). Glycopyrrolate, ethanol and $2 \mathrm{~N} \mathrm{H}_{2} \mathrm{SO}_{4}$ was from VWR (UK). Tiotropium was a gift from Boehringer Ingelheim (Germany). Sterile saline was purchased from Fresenius Kabi Limited (UK) and pentobarbitone from National Veterinary Services Limited (UK). All other agents were purchased from Sigma-Aldrich (UK) unless otherwise described.

\section{Statistics}

Data was expressed as mean \pm S.E.M of $\mathrm{n}$ observations. A $p$ value $<0.05$ was taken as statistically significant, the actual test used is indicated in the figure legends.

\section{Results}

Validation of the LAR model using a clinically relevant glucocorticosteroid

The effect of high dose budesonide was assessed In order to evaluate the clinical relevance of the OVA driven mouse LAR model. OVA challenge resulted in a marked LAR in OVA sensitised mice. This response peaked at $3 \mathrm{~h}$ and lasted for up to $8 \mathrm{~h}$ after challenge. The saline sensitised mice did not display a response following OVA challenge. Budesonide treatment resulted in a significantly decreased LAR in the OVA sensitised/ OVA challenged mice when compared with vehicle treated mice (Fig. 1). No effect of budesonide was observed on the Penh baseline recordings.

\section{Assessing the importance of Alum ${ }^{\mathrm{TM}}$ adjuvant in murine asthma models}

Traditionally, adjuvant has been reported as a requirement when utilising OVA to model features of allergic asthma within murine models. However, when investigating the requirement for Alum ${ }^{\mathrm{TM}}$ adjuvant within the AHR model, it was found not to be essential. Indeed, the group sensitised with vehicle plus OVA conferred comparable AHR to the group sensitised with Alum ${ }^{\mathrm{TM}}$ plus OVA (see Fig. 2 a, b). Eosinophilia was also comparable between the groups (Fig. 2c). Interestingly, Alum ${ }^{\mathrm{TM}}$ adjuvant was found to be a requirement in the sensitisation process for mice to elicit an LAR. Mice sensitised with Alum $^{\mathrm{TM}}$ in addition to OVA antigen elicited a distinct LAR, while mice sensitised with vehicle in addition to OVA antigen did not demonstrate a response (Fig. 2d). It should be noted that negative controls were also included in investigations (i.e. mice sensitised with Alum $^{\mathrm{TM}}$ plus saline without antigen and allergen challenged) and did not elicit responses (data not shown).

\section{Exploring the role of airway sensory nerves in the murine LAR model}

Glycopyrrolate (over the range of MCh challenge doses the approximate $\mathrm{ED}_{50}$ was between 0.001 and $0.01 \mathrm{mg} /$ $\mathrm{kg}$, with the mean Emax of $0.01 \mathrm{mg} / \mathrm{kg}$ ) and Tiotropium (the approximate $\mathrm{ED}_{50}$ was between 0.0001 and $0.001 \mathrm{mg} / \mathrm{kg}$, with the mean Emax of $0.001 \mathrm{mg} / \mathrm{kg}$ ) significantly attenuated AHR to methacholine. The Emax dose values were chosen to use in the mouse LAR model. Glycopyrrolate and Tiotropium failed to impact upon the LAR response but the positive control (Budesonide) significantly attenuated the LAR (Fig. 3). Interestingly, the LAR was still evident in TRPA ${ }^{-1-}$ mice when compared with wildtype controls. In order to confirm the data obtained in the TRPA1 ${ }^{-/-}$mice obtained from Jackson Laboratories an alternative colony of TRPA1-/- mice originally developed by the Julius Lab were obtained and utilised. However, similar results were obtained consistent with the previous experiments showing no difference in the LAR response between the TRPA $^{-1-}$ and wildtype mice (Fig. 4). 

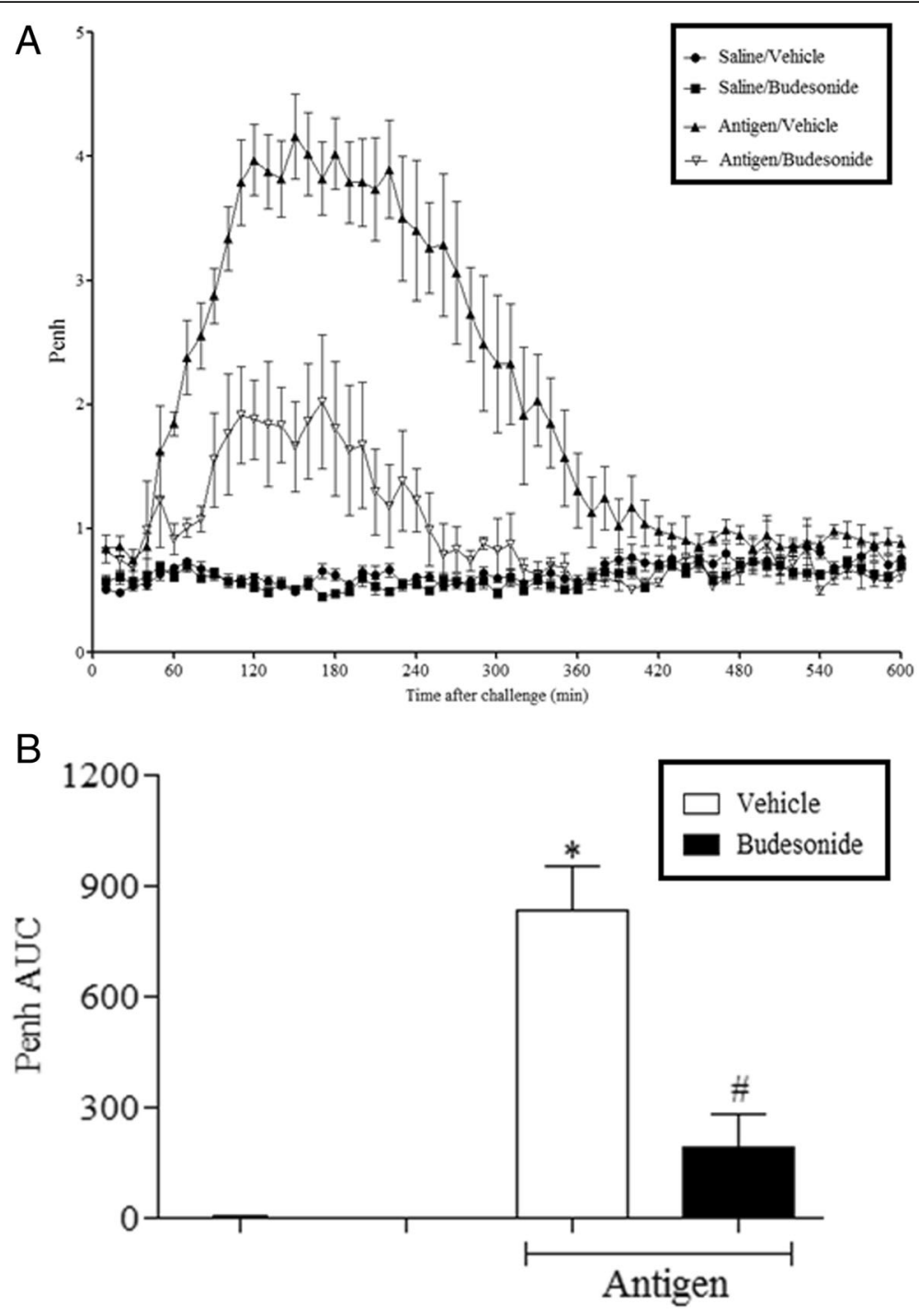

Fig. 1 The effect of Budesonide treatment in the mouse OVA-driven LAR. Immediately following recovery from allergen challenge, mice were placed in WBP chambers and Penh recorded for $12 \mathrm{~h}$. The two bars on the left are the data from the saline challenge/vehicle treated and saline challenged/drug treated, control groups. Data is expressed as a) Penh average over the recording time period; b) Penh Area Under Curve. Data expressed as mean \pm s.e.m. $n=5-8$. Mann-Whitney U-test. ${ }^{*} p<0.05$ Vehicle/Saline compared to Vehicle/Ovalbumin. \#p $<0.05$ Budesonide (3 mg/kg)/Ovalbumin compared to Vehicle/Ovalbumin

Investigating the role of key allergic effector cells in the OVA driven mouse model of LAR

Prior to investigating a role for various key allergic effector cells in the LAR response we evaluated the phenotype of the $\mathrm{CD}^{-/-}, \mathrm{CD}^{-/-}, \mathrm{B}-\mathrm{cell}^{-/-}$and mast$\mathrm{cell}^{-/-}$mice using flow cytometry and histology. The $\mathrm{CD}^{-1-}, \mathrm{CD}^{-1-}$ and B-cell ${ }^{-1-} \mathrm{GM}$ mice were all confirmed to be deficient of their specific knockout cell via flow cytometry (See Fig. 5). Lung tissue populations of $\mathrm{CD}^{+}, \mathrm{CD}^{+}$and $\mathrm{CD} 19^{+}$cells in the knockout mice were found to be comparable to those seen in wildtype mice where the cell type was not the deficient population (data not shown). The mast cell knockout mice were confirmed to be deficient of lung mast cells using the standard histological stain Toluidine Blue on lung tissue slices. No significant differences with respect to the mast cell population in the other GM strains were found compared with the wildtype group (Fig. 6). Baseline levels of eosinophils, neutrophils, alveolar macrophages and monocytes/tissue macrophages were assessed by flow cytometry in wildtype mice compared with the various transgenic mice. No significant differences in these cell types were found across the GM strains compared with the wildtype group (data not shown).

For all experiments, OVA challenge resulted in a marked LAR in wildtype OVA sensitised mice which peaked at $3 \mathrm{~h}$ and lasted for up to $8 \mathrm{~h}$ after challenge, compared to saline sensitised wildtype mice. $\mathrm{CD} 4^{-/-}$and 


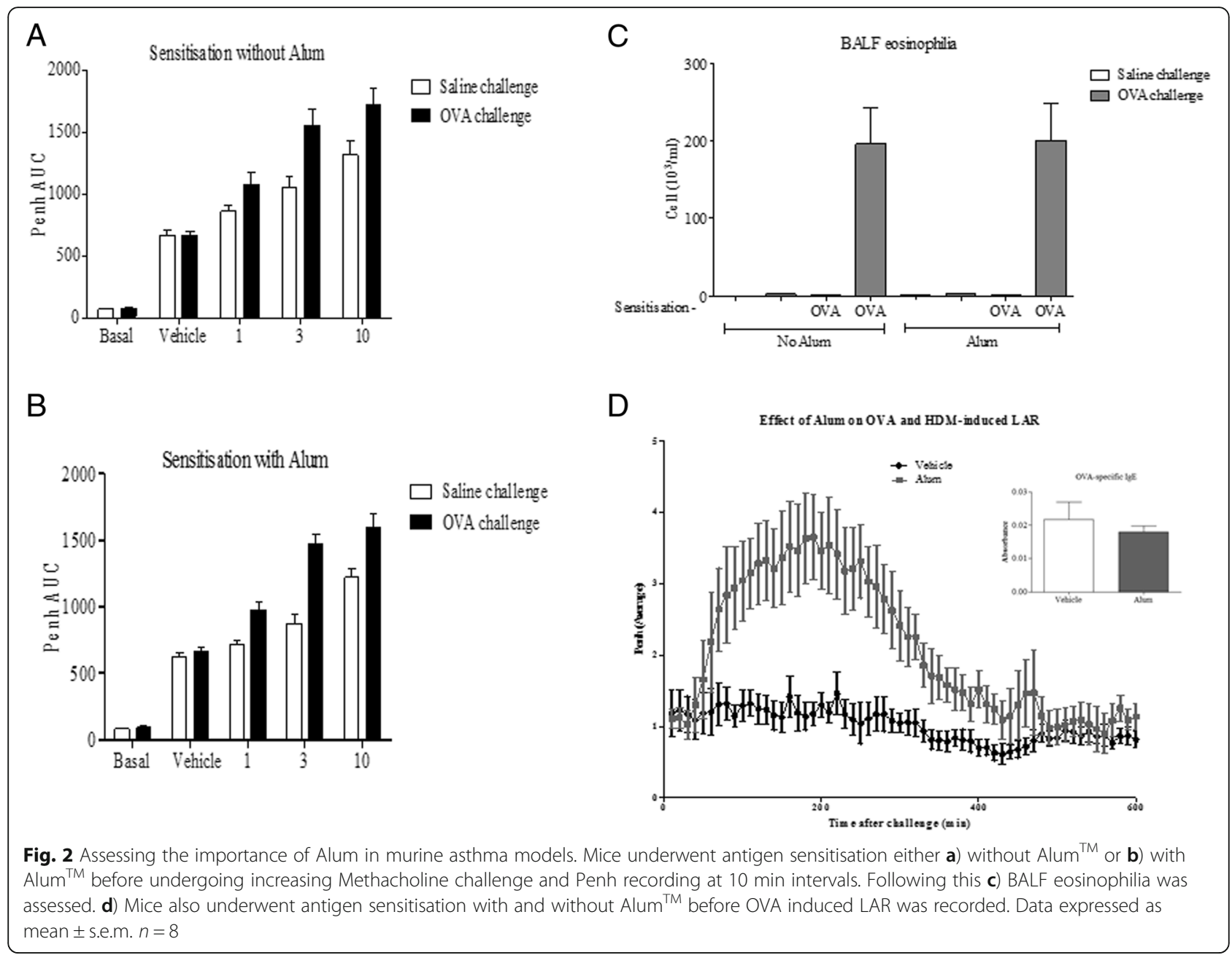

$\mathrm{CD} 8^{-/-}$mice exhibited a baseline response comparable to saline sensitised wildtype mice following OVA challenge. A significant attenuation of response was observed in the OVA sensitized $\mathrm{CD} 4^{-1-}$ mice compared to OVA sensitised wildtype group (see Fig. 7). Interestingly, $\mathrm{CD}^{-1-}$ OVA sensitised and challenged mice exhibited a significantly enhanced response compared to the wildtype OVA sensitised and challenged group (see Fig. 8). Surprisingly, the saline sensitised mast $\mathrm{cell}^{-/-}$, Bcell $^{-1-}$ and $\operatorname{IgE}^{-1-}$ mice had a significantly enhanced response to OVA challenge compared to the saline sensitised wildtype mice. Even more surprisingly, the OVAsensitised mast $\mathrm{cell}^{-/-}$, B-cell ${ }^{-/-}$and $\mathrm{IgE}^{-/}$groups displayed responses to OVA challenge which were not significantly different to that seen in the OVA sensitised wildtype group (Figs. 9, 10 and 11). As expected the total and antigen specific IgE plasma levels were abolished in the IgE ${ }^{-1-}$ mice (Fig. 12). The levels of antigen specific IgE levels were also significantly attenuated in the CD4 ${ }^{-/-}$and $\mathrm{B} \mathrm{cell}^{-/-}$mice, but not the $\mathrm{CD}^{-/-}$or mast cell knockout mice (Fig. 13).

\section{Discussion}

In the search for effective new therapeutics for asthma patient's preclinical models are often utilised to test hypotheses before progression into clinical studies. However, current dogma suggests that preclinical model systems, particularly in the mouse, are often not predictive of therapeutic outcome. Therefore, the aim of this study was to investigate the utility of a mouse model of the LAR as a pre-clinical model, predictive of clinical allergen challenge studies, upon which to assess future asthma therapies. Validation of the model was judged by assessing the impact of a clinically effective glucocorticosteroid, long acting muscarinic receptor and TRPA1 antagonists (previously shown to be effective in the rat LAR response) the need for an adjuvant (Alum ${ }^{\mathrm{TM}}$ ), and a role for key allergic effector cells within the LAR model. Throughout these investigations, Penh was used as an arbitrary measure of airway constriction in order to assess lung function within the models. Although some controversy still exists surrounding the use of Penh, previous work by Raemdonck et al. (2012) [18] 


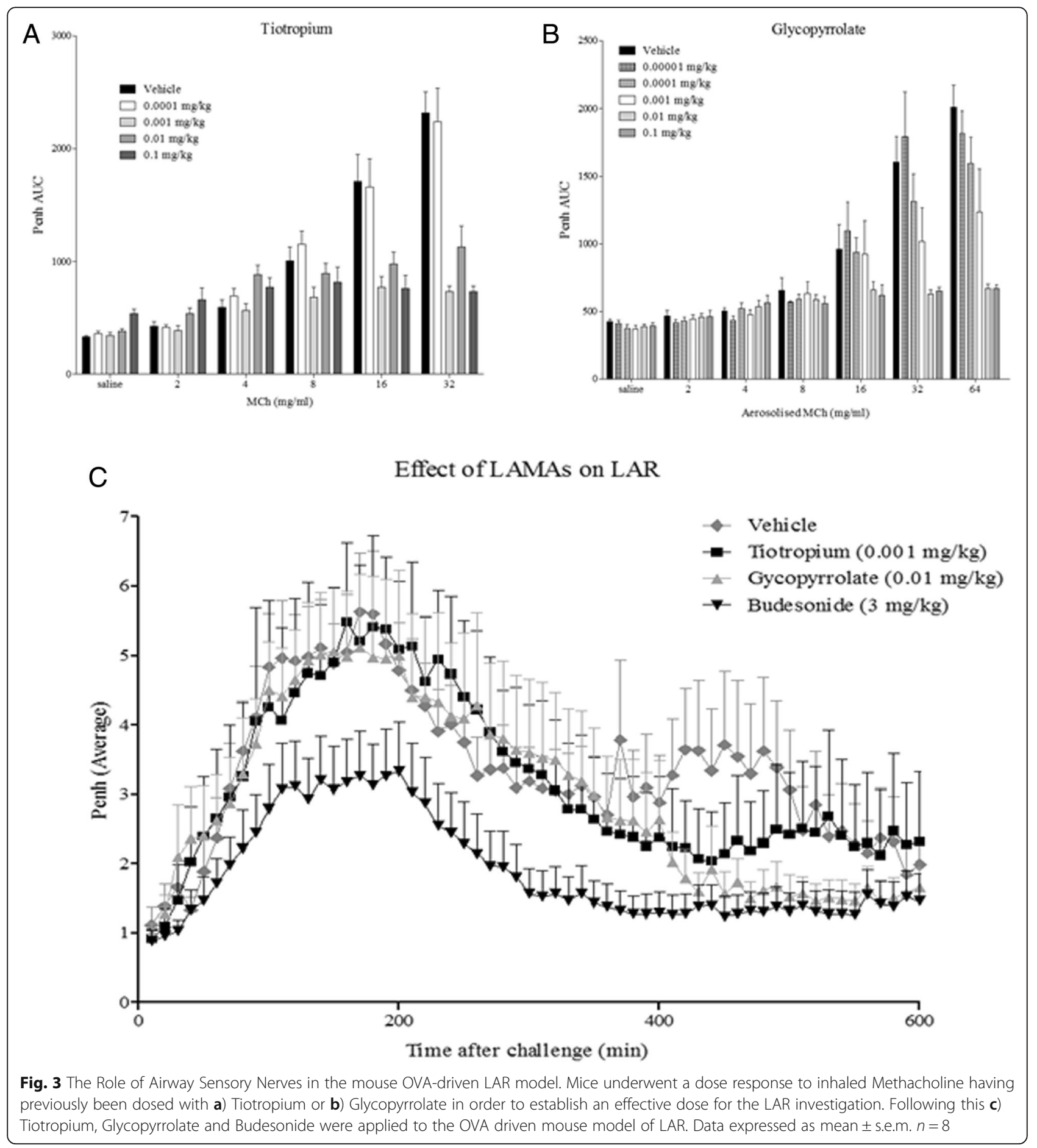

described a role for neuronal reflexes in the LAR and so a conscious modeling system was required. There are currently no alternative ways of attaining these measurements without using restraint, and licensing restrictions would not allow the use of restraint for the prolonged periods of time necessary to achieve the LAR response.

In asthmatic patients, the LAR typically occurs $3-8 \mathrm{~h}$ following allergen exposure [11]. This model demonstrated response time points similar to these with a peak response at $3 \mathrm{~h}$ and a return to baseline at $8 \mathrm{~h}$ post challenge. Budesonide was successful in significantly attenuating the responses in the model, suggesting that the model was displaying bronchoconstriction consistent with the LAR, not the EAR, consistent with clinical studies. In the AHR model, Alum ${ }^{\mathrm{TM}}$ adjuvant was found to be dispensable within the sensitisation process for mice to elicit a response. 

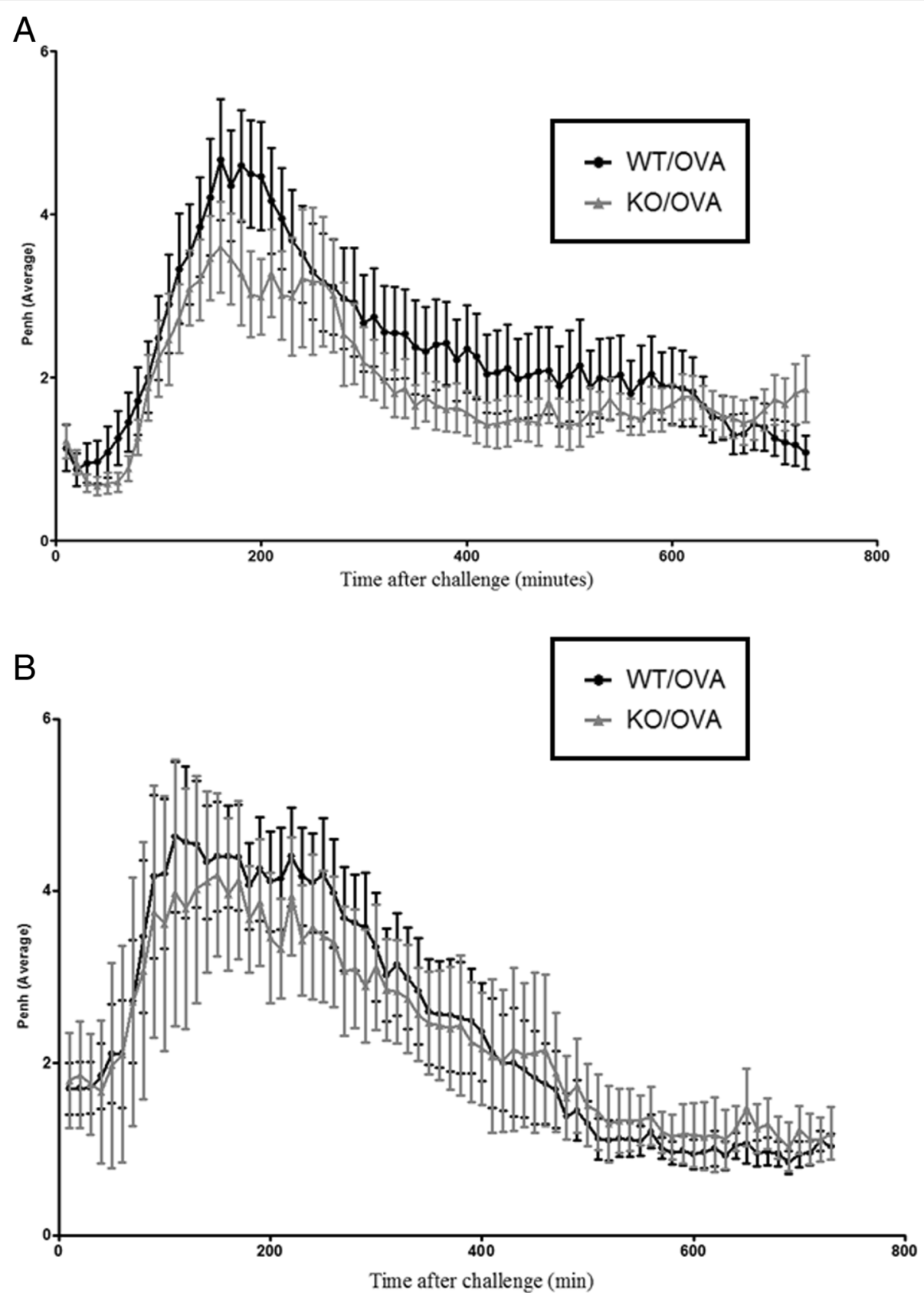

Fig. 4 Assessing the importance of TRPA1 in the mouse OVA-driven LAR model. TRPA1-/- mice were obtained from either a) Jackson laboratories or b) David Julius Laboratory before being applied to the mouse OVA-driven LAR model. Data expressed as mean \pm s.e.m. $n=8$

This was also the case when observing eosinophilia within the models. In contrast, in the murine LAR model, Alum $^{\mathrm{TM}}$ was found to be a requirement in the sensitisation process for mice to display an LAR. This suggests that different mechanisms may be driving the AHR and LAR. Numerous theories for the mechanism of action of Alum $^{\mathrm{TM}}$ have been suggested but overall the mechanisms driving the adjuvant activity of Alum ${ }^{\mathrm{TM}}$ and its contribution to the LAR remain a mystery but could question the clinical relevance of the LAR in this model.
The aetiology of the LAR has been associated with sensory nerve interactions. Raemdonck et al. (2012) showed that the LAR but not the EAR was lost under general anaesthesia in the Brown Norway rat. Further investigation led to the conclusion that stimulation of airway sensory nerves via TRPA1 channels leading to parasympathetic, cholinergic constrictor responses, is involved in driving the allergen induced LAR. Glycopyrrolate and Tiotropium, used at doses that blocked bronchoconstriction to methacholine in the AHR model, 

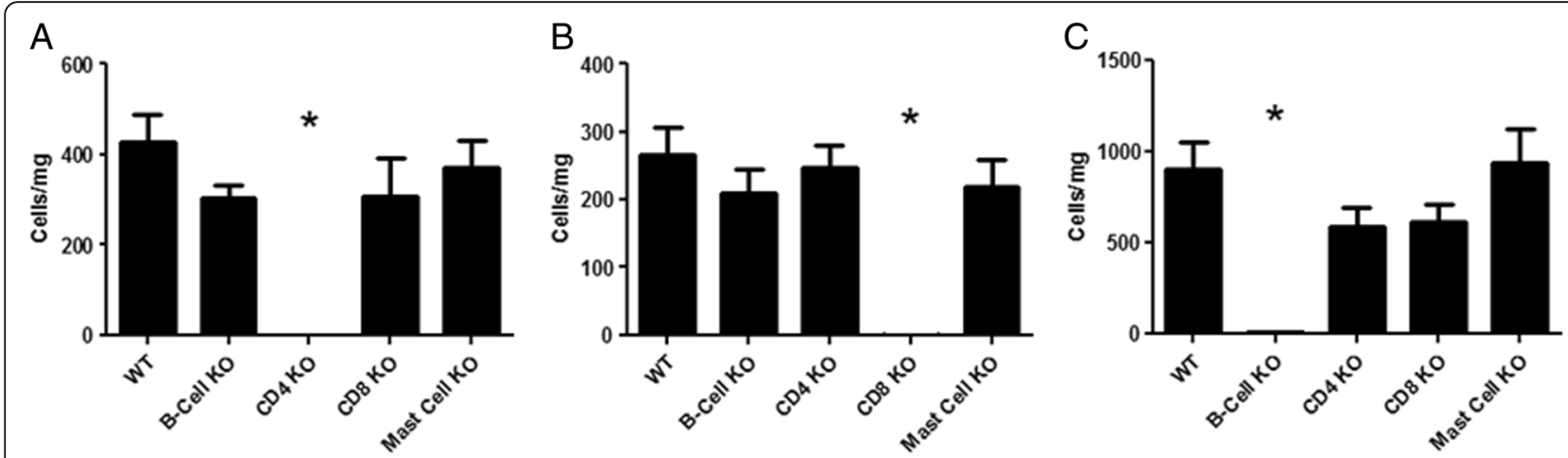

Fig. 5 Validation of Lymphocyte Populations in Genetically Modified Mice by Flow Cytometry. Leukocytes from the lung tissue of wildtype (C57BL/6), B-cell-/-, CD4-/-, CD8-/- and Mast-cell-/- naïve male mice were attained via enzymatic digest. Flow Cytometry was used to assess the numbers of: $\mathbf{a})$ CD4+ cells; $\mathbf{b})$ CD8+ cells and $\mathbf{c}$ ) CD19+ cells. Data is expressed as mean cell number per mg of lung tissue \pm s.e.m. $n=6-8$. One-way ANOVA, Kruskal-Wallis test with post-hoc comparisons using Dunn's multiple comparison test. ${ }^{*} p<0.05$ compared to wildtype control group

failed to impact upon the response within the OVA driven murine model of LAR. This suggests that airway sensory nerves are not involved in the mechanisms driving the LAR in the mouse model. This is in contrast to previous findings in the more established Brown Norway rat model of LAR, but also in a Guinea-pig model of LAR [11, 33]. When two separate colonies of TRPA1 knockout mice were utilized there was still no attenuation in the LAR response when compared with wildtype controls. This suggests that the TRPA1 channel is not essential in the mouse model of LAR and argues against

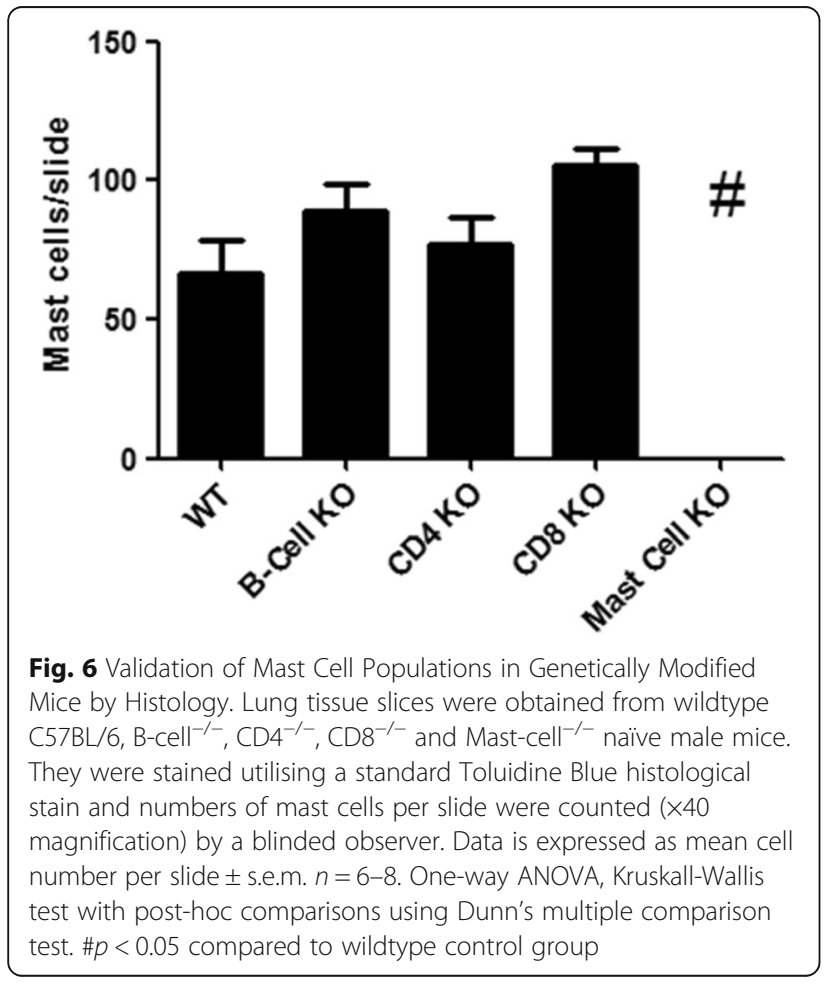

the contribution of sensory nerve activation. This is again in stark contrast to previous findings of the LAR observed in the Brown Norway rat and Guinea-Pig. Future clinical studies, utilising clinically approved long acting muscarinic receptor antagonists, should ascertain whether the mouse model of LAR or other species (i.e. Brown Norway rat and Guinea-Pig models of LAR) are more credible when modeling this feature of asthma.

The final aim of this investigation was to explore the relevance of key allergic effector cells in the LAR by utilising GM mice lacking the relevant immune cell types. The $\mathrm{CD}^{-/-}$mice displayed a much attenuated response compared with wildtype mice, suggesting a role for CD4 + cells in the mechanisms driving the LAR consistent with clinical studies that have identified increased levels of $\mathrm{CD}^{+}$cells in asthmatic bronchial biopsies compared with healthy controls [34]. Allergen challenge has been associated with less circulating $\mathrm{CD}^{+} \mathrm{T}$-lymphocytes in isolated early responders compared with dual responders (those displaying an EAR and LAR) [35]. Increased levels of $\mathrm{CD}^{+}$cells have also been found in the BAL fluid of dogs with ragweed allergy at $4 \mathrm{~h}$ post allergen challenge [36]. Enhanced levels of CD4 $4^{+}$cells in murine models of asthma have also been shown to correlate with the LAR [24]. Depletion and adoptive transfer studies in rats and mice have also deduced a central role for $\mathrm{CD}^{+}$cells within this response [37-40].

The $\mathrm{CD}^{-/-}$mice displayed a significantly enhanced response compared to wildtype mice, implicating a protective role for $\mathrm{CD}^{+}$cells within the LAR. Increased numbers of $\mathrm{CD}^{+} \mathrm{T}$-cells have been found in the airway submucosa of sensitised rats exposed to OVA and depletion of these cells using a monoclonal antibody has been shown to enhance the LAR [40-43]. Adoptive transfer studies have shown that the application of sensitised $\mathrm{CD}^{+}$cells into rat models of the LAR resulted in 

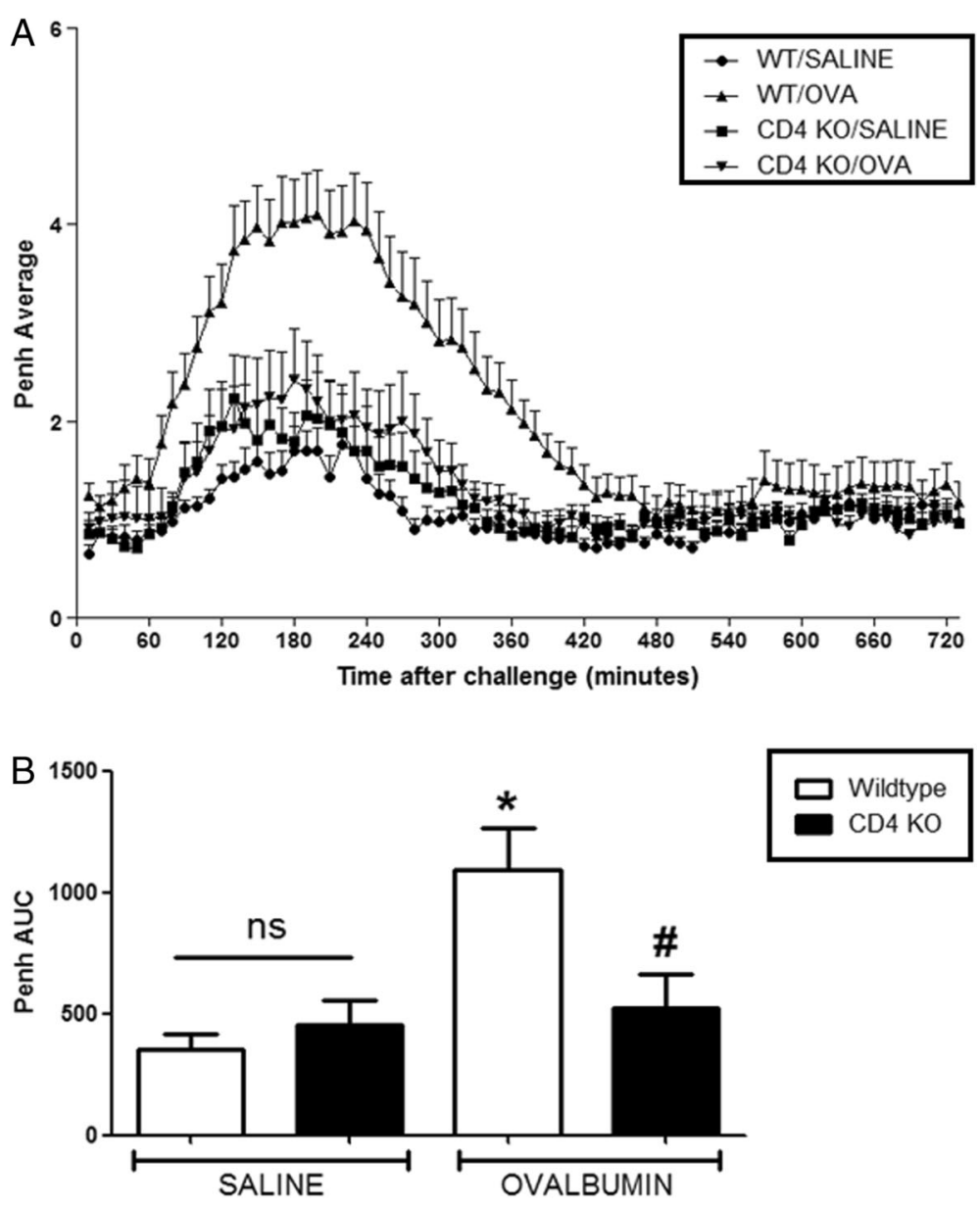

Fig. 7 The Role of $\mathrm{CD}^{+}$Cells in the OVA-driven Mouse Model of LAR. Immediately following recovery from allergen challenge, mice were placed in WBP chambers and Penh recorded for $12 \mathrm{~h}$. Data is expressed as a) Penh average over the recording time period; b) Penh Area Under Curve. Data expressed as mean \pm s.e.m. $n=13-21$. Mann-Whitney U-test. ${ }^{*} p<0.05$ wildtype Saline sensitised compared to wildtype Ovalbumin sensitised groups. \#p $<0.05 \mathrm{CD}^{-/-}$Ovalbumin sensitised compared to wildtype Ovalbumin sensitised groups. No significant difference between groups is denoted $n s$

suppression of the response upon allergen re-exposure [44]. This LAR suppression has been shown to correlate with enhanced levels of the cytokine IFN- $\gamma$ in the BAL fluid and the administration of this cytokine to rat models can reduce the $\operatorname{LAR}[45,46]$. $\mathrm{CD} 8^{+} \mathrm{T}$-cells are known producers of IFN- $\gamma$ and so could elicit a protective effect in the allergic airway via this cytokine [47, 48]. Indeed, adoptive transfer studies have shown that application of $\mathrm{CD}^{+} \gamma \delta$ T-cells into rat models of allergic asthma resulted in a diminished LAR. Pre-treatment of $\mathrm{CD}^{+} \gamma \delta$ T-cells with an antisense oligonucleotide to inhibit IFN- $\gamma$ before transfer into sensitised recipients resulted in complete recovery of the LAR [49]. It has been shown in numerous investigations that IFN- $\gamma$ can suppress the proliferation of Th2 type $\mathrm{CD} 4^{+} \mathrm{T}$-cells and it has been shown to inhibit the infiltration of $\mathrm{CD} 4^{+}$cells into the airways in a mouse allergic asthma model [50-54].
Isogai and colleagues showed that transferring $\mathrm{CD}^{+}$cells into recipient rats resulted in an LAR upon allergen exposure; and in the same study showed the depletion of $\mathrm{CD} 8^{+}$ cells using monoclonal antibodies resulted in an enhanced LAR [55]. The application of GM mice deficient in CD4 ${ }^{+}$and $\mathrm{CD}^{+}$cell types when exploring the specific mechanisms behind the LAR is novel. On the whole previous studies have employed monoclonal antibodies in allergic asthma models which may target other cell types nonspecifically. The results obtained in this investigation correspond with the idea that $\mathrm{CD} 4^{+} \mathrm{T}$-cells are drivers of the LAR and $\mathrm{CD}^{+}$T-cells have a protective role in this response which is consistent with the existing literature.

As expected OVA-sensitised wildtype mice had enhanced levels of plasma OVA-specific IgE which also corresponded with the presence of an LAR. The CD4 ${ }^{-/}$mice had significantly decreased levels of plasma 

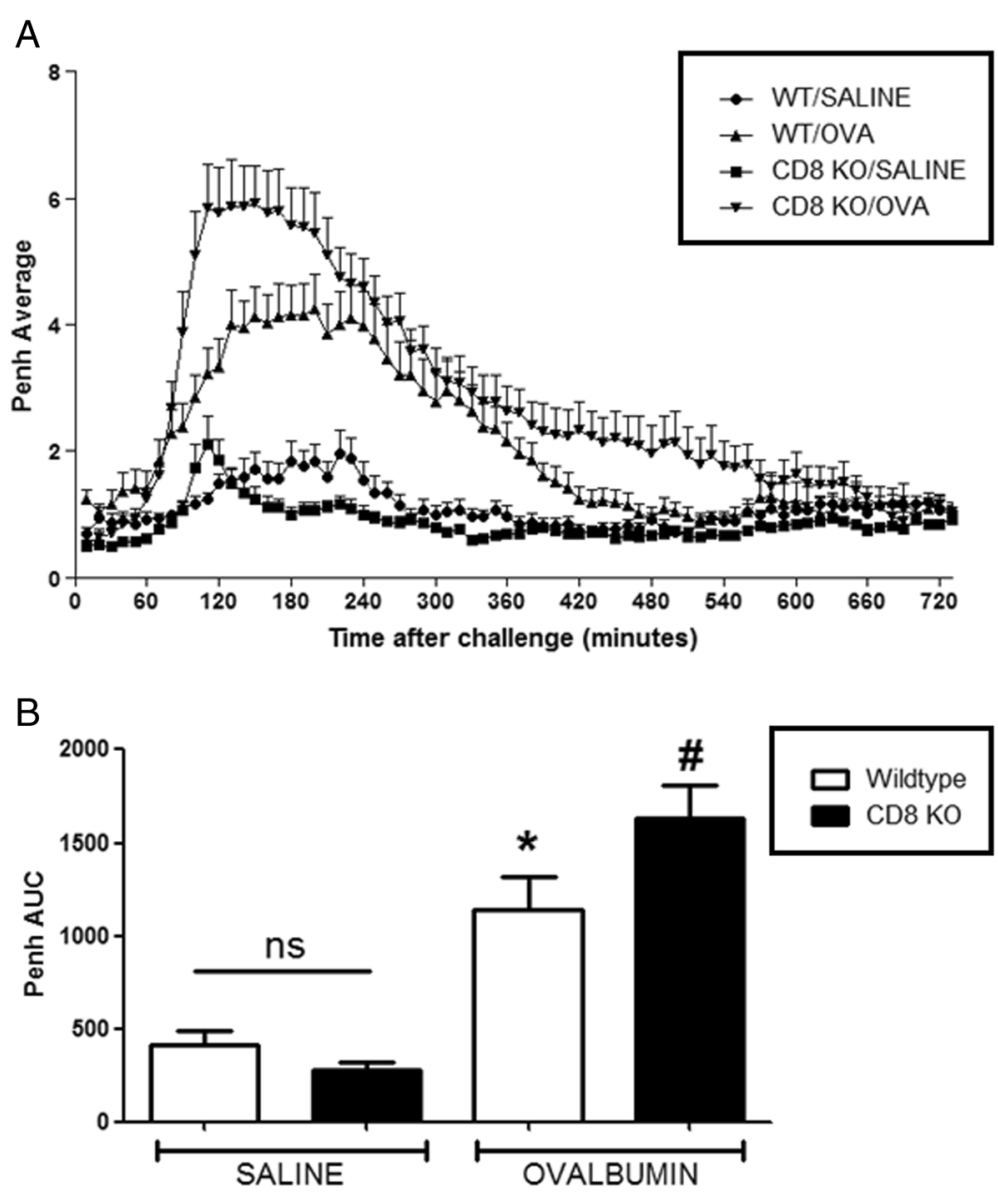

Fig. 8 The Role of $\mathrm{CD}^{+}$Cells in the OVA-driven Mouse Model of LAR. Immediately following recovery from allergen challenge, mice were placed in WBP chambers and Penh recorded for $12 \mathrm{~h}$. Data is expressed as a) Penh average over the recording time period; b) Penh Area Under Curve. Data expressed as mean \pm s.e.m. $n=14-17$. Mann-Whitney U-test. ${ }^{*} p<0.05$ wildtype Saline sensitised compared to wildtype Ovalbumin sensitised groups. \#p<0.05 CD8 ${ }^{-1-}$ Ovalbumin sensitised compared to wildtype Ovalbumin sensitised groups. No significant difference between groups is denoted ns

OVA-specific IgE and the B-cell deficient mice had negligible levels of plasma allergen specific IgE. The plasma IgE levels were found to be comparable to the corresponding wildtype groups, in the $\mathrm{CD}^{-/-}$and mast cell deficient mice. OVA sensitised and challenged B-cell ${ }^{-/}$, Mast cell ${ }^{-/}$and $\mathrm{IgE}^{-/-}$mice displayed a response which was comparable to that seen in wildtype mice, suggesting that these cell types and mediators are not involved in the mechanisms driving the LAR. Interestingly, however, these particular GM mouse strains also exhibited an enhanced baseline response even though they were not sensitised to allergen, making the results difficult to interpret.

Previous pre-clinical studies addressing the role of Bcells, Mast cells and IgE in the LAR have been inconclusive. Mizutani et al. (2012) demonstrated that mice sensitised with OVA-specific IgE displayed an LAR upon OVA challenge [56]. Inhibitors of mast cell products such as cysteinyl leukotrienes have been shown to inhibit the LAR at least partially [13, 57]. Adoptive transfer of $\mathrm{CD}^{+}$and $\mathrm{CD}^{+}$cells into a rat model of LAR noted no changes in the EAR and serum IgE levels $[40,46]$. Some clinical studies have indicated a prominent role for these cell types and mediators in the LAR. Increased numbers of mast cells and increased levels of IgE in BAL fluid has been associated with the magnitude of the LAR $[58,59]$. Patients treated with corticosteroids (which inhibit the LAR) have been shown to have decreased numbers of mast cells in the smooth muscle and epithelium [60]. DSCG, a known mast cell stabiliser, has been shown to inhibit the LAR in asthmatic patients [61-64]. Anti-IgE monoclonal antibodies have also been shown to suppress allergen induced late phase bronchoconstriction [64-67].In contrast, other clinical studies have alluded to mechanisms independent of B-cells, Mast cells and IgE to be important in driving the LAR. 

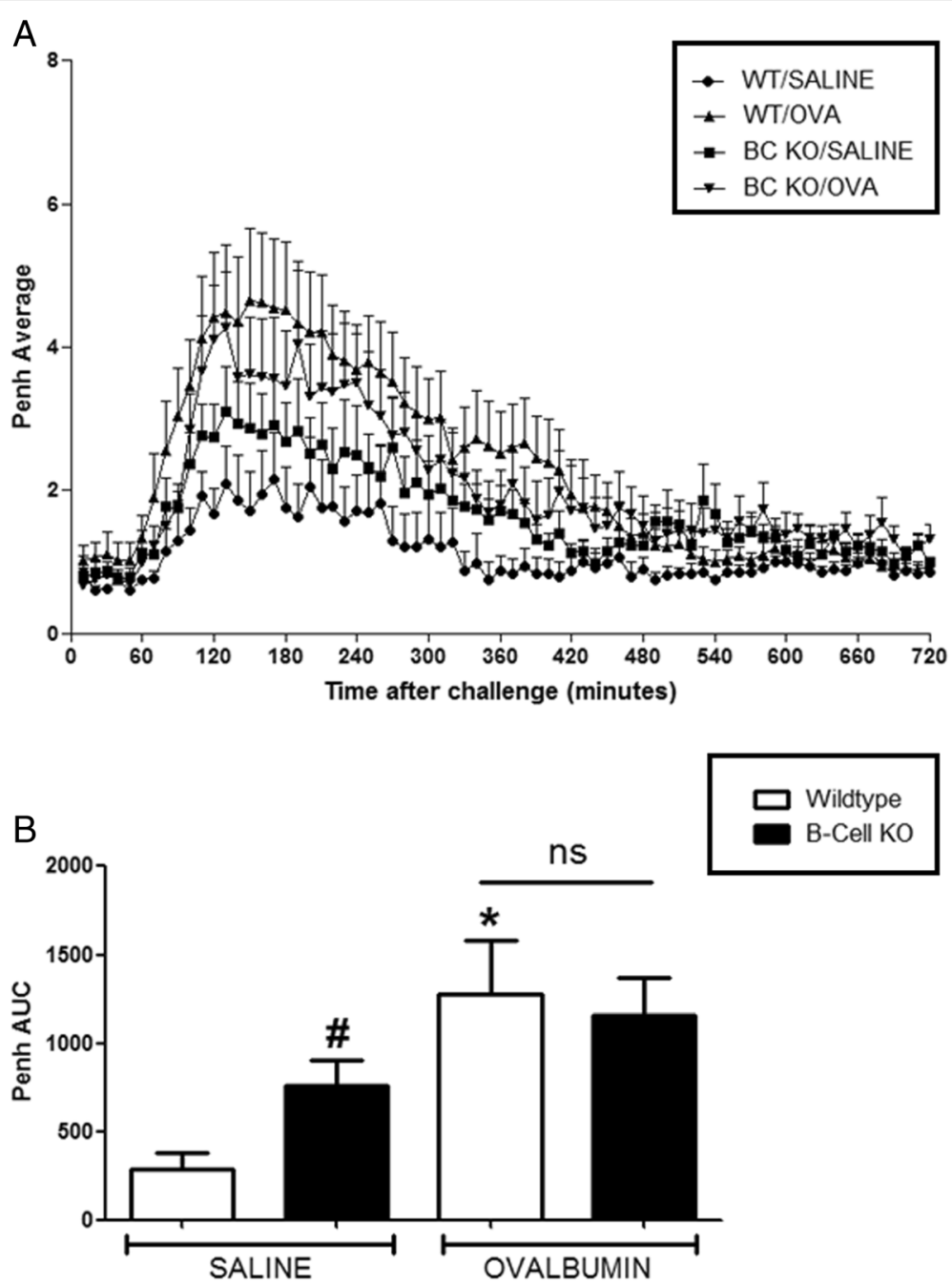

Fig. 9 The Role of B-Cells in the OVA-driven Mouse Model of LAR. Immediately following recovery from allergen challenge, mice were placed in WBP chambers and Penh recorded for $12 \mathrm{~h}$. Data is expressed as a) Penh average over the recording time period; b) Penh Area Under Curve. Data expressed as mean \pm s.e.m. $n=12-14$. Mann-Whitney U-test. ${ }^{*} p<0.05$ wildtype Saline sensitised compared to wildtype Ovalbumin sensitised groups. \#p $<0.05$ wildtype Saline sensitised compared to B-cell ${ }^{-/-}$Saline sensitised groups. No significant difference between groups is denoted ns

In asthmatic patients, Durham et al. (1984) failed to see an association between total or allergen specific $\operatorname{IgE}$ and the LAR [68]. Total IgE has been shown to be a poor indicator of the LAR [69]. In the African population, serum levels of IgE have even been reported to be higher in non-asthmatics compared to asthmatics [70]. Studies involving the inhalation of T-cell peptides derived from the feline allergen Fel $d 1$ demonstrated the induction of an isolated LAR without an accompanying EAR, implying the LAR to be T-cell dependent and IgE independent [71]. Khan et al. (2000) demonstrated that while Cyclosporin A decreased the LAR in patients, no effects were seen on the EAR indicating that the LAR occurs independently of the B-cell-Mast cell- IgE products axis [72]. Overall, the existing literature on the subject of the involvement of B-cells, Mast cells and IgE in the LAR is sparse and conflicting probably due to the limited tools available for examining the role of these cells and mediators in the LAR. Specificity issues concerning depleting antibodies in asthma investigations have been raised. For example, the antibody MAR-1, targeting the high affinity receptor FceRI has not only been shown to inhibit mast cell driven processes, but has been shown to activate mast cells [73-75].

Cell deficient strains have been used by others investigating other features of asthma such as AHR and airway 

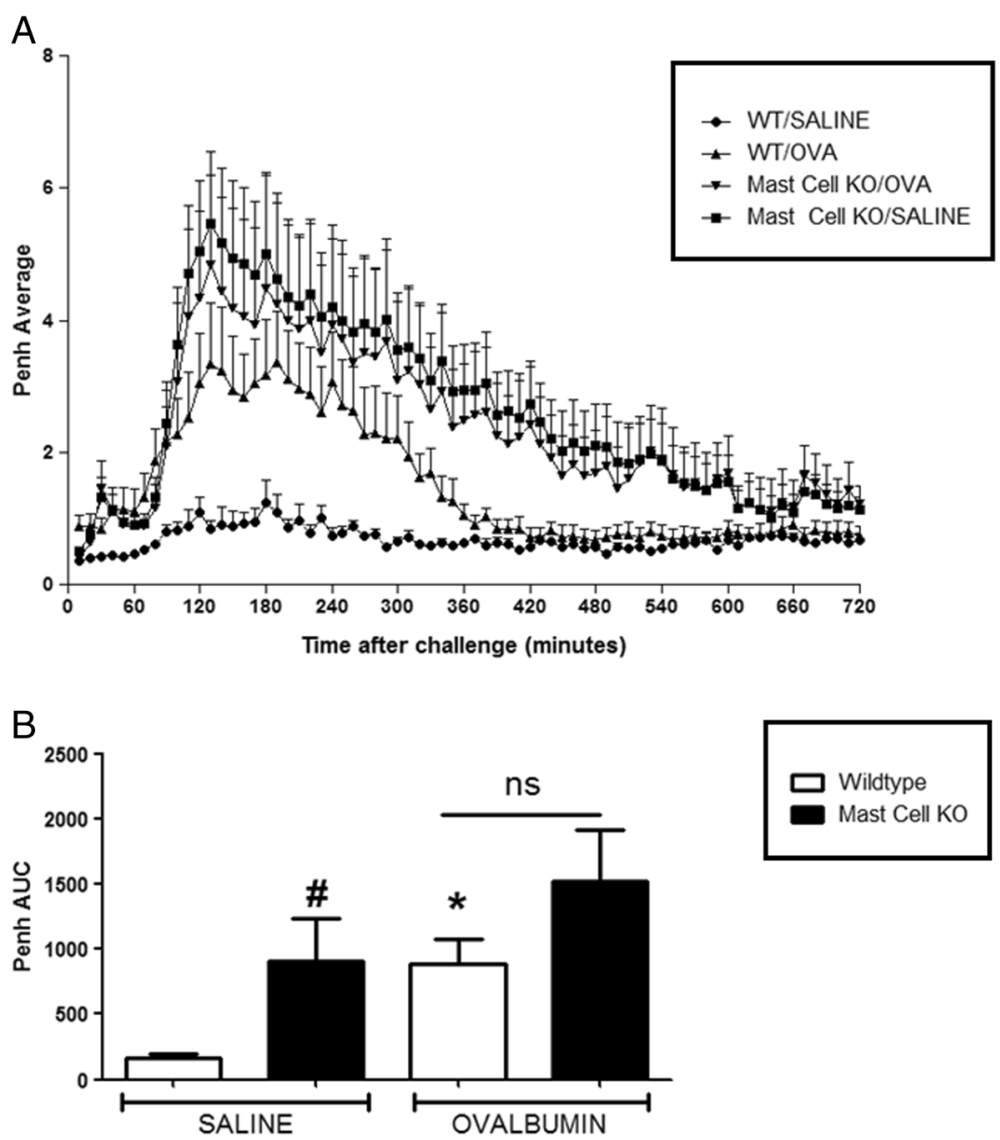

Fig. 10 The Role of Mast Cells in the OVA-driven Mouse Model of LAR. Immediately following recovery from allergen challenge, mice were placed in WBP chambers and Penh recorded for $12 \mathrm{~h}$. Data is expressed as a) Penh average over the recording time period; b) Penh Area Under Curve. Data expressed as mean \pm s.e.m. $n=8-12$. Mann-Whitney U-test. ${ }^{*} p<0.05$ wildtype Saline sensitised compared to wildtype Ovalbumin sensitised groups. $\# p<0.05$ wildtype Saline sensitised compared to Mast cell ${ }^{-/}$Saline sensitised groups. No significant difference between groups is denoted $n s$

inflammation. These investigations have yielded conflicting results and this variation seen in experimental results has been attributed to differences in genetic background, differences in sensitisation and challenge protocols and also the use of adjuvants [76]. A bigger question has also been raised as to the suitability of murine asthma models [77]. It should be noted that there are differences between mice and humans with respect to lung mast cell populations. Humans mast cells are found around the airways and vessels in both the large and small airways and in the parenchyma, whereas in mice, mast cells are mainly located in the trachea and larger airways [78, 79]. In mice, mast cell driven responses such as the EAR are due to the release of $5-\mathrm{HT}$, compared to human mast cells which secrete histamine and other preformed mediators such as cysteinyl leukotrienes [13-15, 80]. Therefore, it could be that when investigating mast cell responses (and possibly other linked cells and mediators such as B-cells and IgE) the mouse is not the best species to employ.

\section{Conclusion}

In summary, explorations of the murine model of LAR demonstrated that the response was induced by allergen challenge, steroid sensitive and T-cell dependant. These features are consistent with the clinical phenotype observed in clinical allergen challenge studies. However, the requirement for Alum ${ }^{\mathrm{TM}}$ adjuvant leads to questions surrounding the clinical validity of the model. The results obtained when exploring a role for airway sensory nerves and the TRPA1 ion channel in this model were not consistent with results obtained in other species such as the Brown Norway rat and Dunkin Hartley guinea-pig. The stark contrast in results should lead to careful consideration of which species to utilise in preclinical asthma models for future studies. Further investigation into the role of airway sensory nerves in clinical investigations is warranted and results from future studies could allow decisions to be made on the optimal species to utilise when modelling the LAR pre-clinically. When 

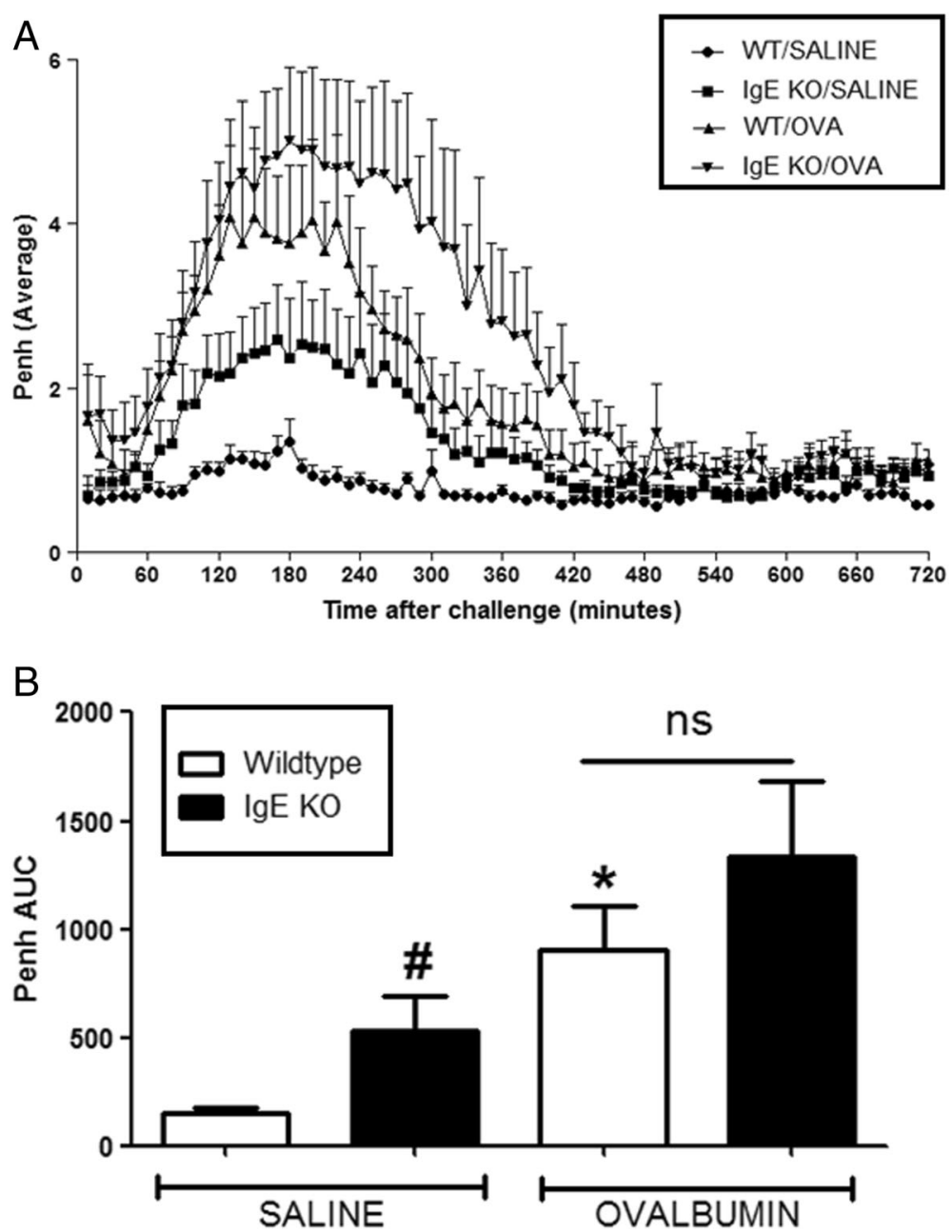

Fig. 11 The Role of IgE in the OVA-driven Mouse Model of LAR. Immediately following recovery from allergen challenge, mice were placed in WBP chambers and Penh recorded for $12 \mathrm{~h}$. Data is expressed as a) Penh average over the recording time period and b) Penh Area Under Curve. Data expressed as mean \pm s.e.m. $n=6-9$. Mann-Whitney U-test. ${ }^{*} p<0.05$ wildtype Saline sensitised compared to wildtype Ovalbumin sensitised groups. \#p $<0.05$ wildtype Saline sensitised compared to $\mathrm{lg}^{-/-}$Saline sensitised groups. No significant difference between groups is denoted $n s$
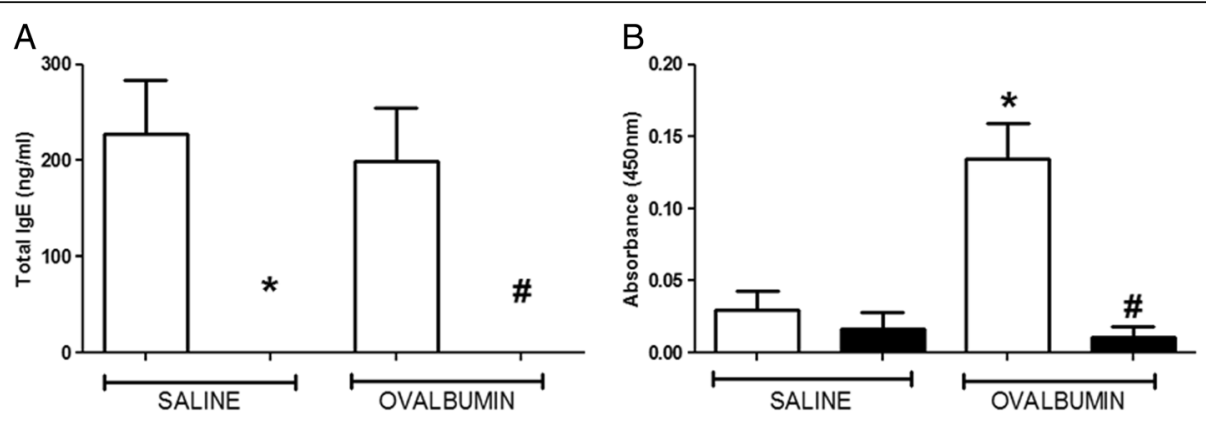

$\square$ Wildtype $\square \operatorname{lgE~KO}$

Fig. 12 Plasma lgE Levels in IgE Deficient Mice. Following Penh recordings, blood samples were attained via cardiac puncture and plasma samples assessed for a) Total IgE and $\mathbf{b})$ OVA-Specific IgE via ELISA. IgE knockout mice in comparison to wildtype groups were assessed. Data is expressed as raw absorbance values taken at $450 \mathrm{~nm} \pm$ s.e.m. $n=6-9$. Mann-Whitney U-test. ${ }^{*} p<0.05$ wildtype Saline sensitised compared to Wildtype Ovalbumin sensitised groups. \#p $<0.05 \mathrm{lgE}^{-/-}$Ovalbumin sensitised compared to wildtype Ovalbumin sensitised groups 

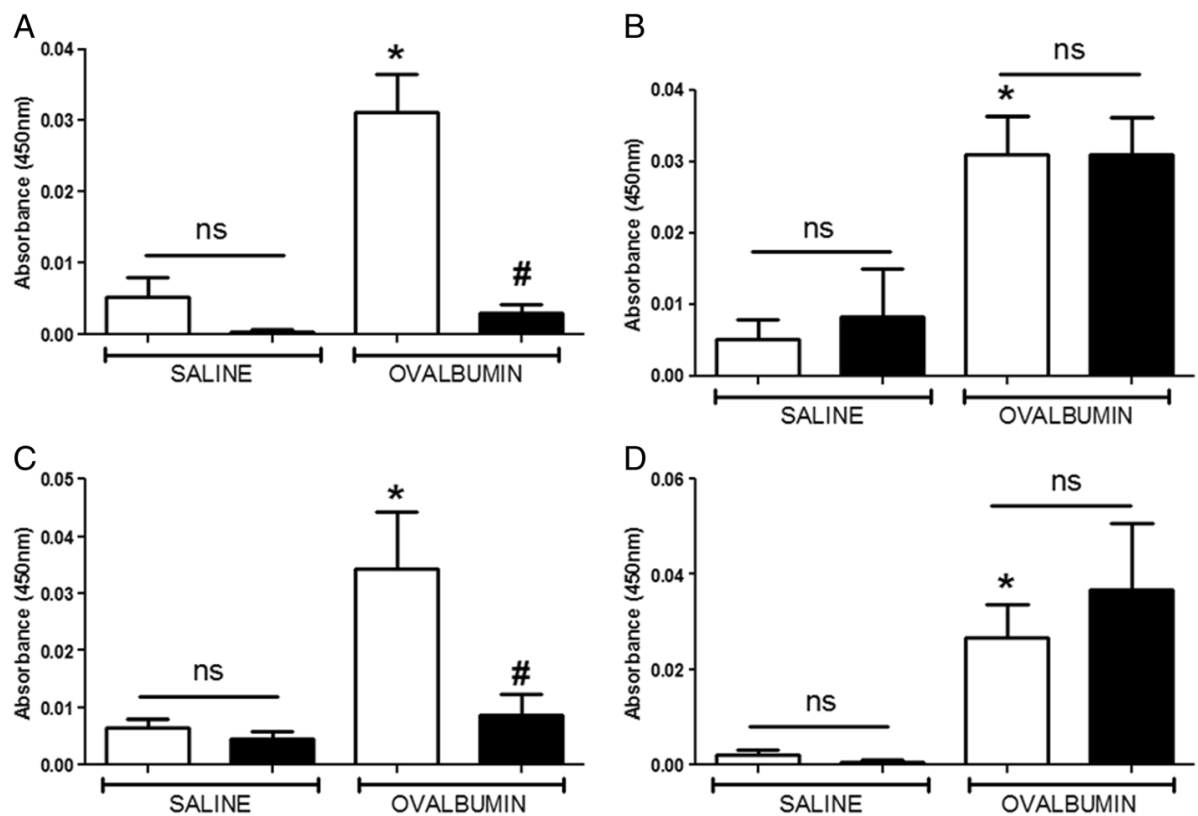

Fig. 13 Plasma OVA-Specific IgE Levels in Cell Deficient Mice. Following Penh recordings, blood samples were attained via cardiac puncture and plasma samples assessed for OVA-Specific IgE via ELISA. Genetically modified strains in comparison to wildtype groups assessed were: a) CD4 ${ }^{-1-}$; b) $\mathrm{CD}^{-1-}$; c) B-cell ${ }^{-/-}$and $\mathbf{d}$ ) Mast cell ${ }^{-/-}$. Data is expressed as raw absorbance values taken at $450 \mathrm{~nm} \pm$ s.e.m. $n=6-11$. Mann-Whitney $U$-test. ${ }^{*} p<0.05$ wildtype Saline sensitised compared to wildtype Ovalbumin sensitised groups. \# $p<0.05$ Knockout Ovalbumin sensitised compared to wildtype Ovalbumin sensitised groups. No significant difference between groups is denoted $n s$

exploring the role of key effector cells no conclusions could be made regarding the contribution of mast cells, B-cells and IgE to the LAR. In conclusion, even though certain features of the mouse LAR model are considered to be clinically relevant, other anomalies lead us to question the validity of using a murine pre-clinical model of LAR upon which to assess future asthma therapies.

\section{Additional file}

Additional file 1: The ARRIVE Guidelines Checklist Animal Research:

Reporting In Vivo Experiments. (PDF $1068 \mathrm{~kb}$ )

\section{Abbreviations}

AHR: Airway hyperresponsiveness; Alum: 20 mg/ml aluminium hydroxide and $20 \mathrm{mg} / \mathrm{ml}$; AUC: Area under the curve; BALF: Bronchoalveolar lavage fluid; BSA: Bovine serum albumin; CD: Cluster of differentiation; ELISA: EnzymeLinked Immunosorbent Assay; FEV 1 : Forced expiratory volume in $1 \mathrm{~s}$; HRP: Horseradish peroxidase; i.n.: Intranasal; i.p.: Intraperitoneal;

i.t.: Intratracheal; IgE: Immunoglobulin E; KO: Knockout; LAR: Late asthmatic response; OVA: Ovalbumin; PBS: Phosphate buffered saline; Penh: Enhanced pause; S.E.M.: Standard error of the mean; TMB: 3,3',5,5'-Tetramethylbenzidine; WBP: Whole body plethysmograph; WT: Wild type

\section{Acknowledgements}

Not applicable.

\section{Funding}

Studies were supported by the Medical Research Council; (MRC, UK) (MR/ K020293/1). KB was supported by an MRC studentship.
Availability of data and materials

Please contact author for data requests.

Authors' contributions

Conception and design: $K B, M A B$ and $M G B$; data generation, analysis and interpretation: $K B, K R, R S, M A B$ and $M G B$; writing the paper; $K B, M G B$ and $M A B$. All authors reviewed the manuscript and approved the final draft.

Competing interests

All authors declare that they have no competing interests.

Consent for publication

Not applicable.

Ethics approval and consent to participate

Not applicable.

\section{Publisher's Note}

Springer Nature remains neutral with regard to jurisdictional claims in published maps and institutional affiliations.

\section{Author details}

${ }^{1}$ Respiratory Pharmacology, Airway Disease Section, National Heart and Lung Institute, Faculty of Medicine, Imperial College London, Exhibition Road, London SW7 2AZ, UK. ²Department of Anatomy, Faculty of Medicine, University of Porto, Alameda Prof. Hernâni Monteiro, 4200-319 Porto, Portugal. ${ }^{3}$ Center for Health Technology and Services Research (CINTESIS), Faculty of Medicine, University of Porto, Rua Dr. Plácido da Costa, 4200-450 Porto, Portugal. ${ }^{4}$ Leukocyte Biology Section, National Heart and Lung Institute, Imperial College London, London, UK. ${ }^{5}$ Asthma UK Centre in Allergic Mechanisms of Asthma, Imperial College London, London, UK. 


\section{Received: 30 September 2016 Accepted: 28 March 2017 Published online: 11 April 2017}

\section{References}

1. Lemanske Jr RF, Busse WW. 6. Asthma. J Allergy Clin Immunol. 2003;111: S502-19. 2003/02/20 ed.

2. Levy ML, Fletcher M, Price DB, Hausen T, Halbert RJ, Yawn BP. International Primary Care Respiratory Group (IPCRG) Guidelines: diagnosis of respiratory diseases in primary care. Prim Care Respir J. 2006;15:20-34. 2006/05/17 ed.

3. Bateman ED, Hurd SS, Barnes PJ, Bousquet J, Drazen JM, Fitzgerald M, et al. Global strategy for asthma management and prevention: GINA executive summary. Eur Respir J. 2008;31:143-78. 2008/01/02 ed.

4. Global Initiative for Asthma. Global Strategy for Asthma Management and Prevention, 2016. Available from: http://ginasthma.org/archived-reports/.

5. World Health Organization. Global surveillance, prevention and control of chronic respiratory diseases: a comprehensive approach, 2007. Available online at http://www.who.int/gard/publications/GARD\%20Book\%202007.pdf.

6. Masoli M, Fabian D, Holt S, Beasley R. The global burden of asthma: executive summary of the GINA Dissemination Committee report. Allergy. 2004;59:469-78. 2004/04/15 ed.

7. Akinbami L, Moorman JE, Liu X. Asthma prevalence, health care use, and mortality: United States, 2005-2009. Natl Heal Stat Rep. 2011;12(32):1-14. 2011/03/02 ed.

8. Fahy JV. Type 2 inflammation in asthma - present in most, absent in many. Nat Rev Immunol. 2015;15:57-65.

9. Holgate ST. The airway epithelium is central to the pathogenesis of asthma. Allergol Int. 2008;57:1-10.

10. Holgate ST. Pathogenesis of asthma. Clin Exp Allergy. 2008;38:872-97. 2008/ 05/24 ed.

11. Booij-Noord H, Orie NG, De Vries K. Immediate and late bronchial obstructive reactions to inhalation of house dust and protective effects of disodium cromoglycate and prednisolone. J Allergy Clin Immunol. 1971;48: 344-54. 1971/12/01 ed.

12. O'Byrne PM, Gauvreau GM, Brannan JD. Provoked models of asthma: what have we learnt? Clin Exp Allergy. 2009;39:181-92.

13. Roquet A, Dahlén $B$, Kumlin $M$, Ihre $E$, Anstrén $G$, Binks $S$, et al. Combined antagonism of leukotrienes and histamine produces predominant inhibition of allergen-induced early and late phase airway obstruction in asthmatics. Am J Respir Crit Care Med. 1997;155:1856-63.

14. Curzen N, Rafferty P, Holgate ST. Effects of a cyclo-oxygenase inhibitor, flurbiprofen, and an $\mathrm{H} 1$ histamine receptor antagonist, terfenadine, alone and in combination on allergen induced immediate bronchoconstriction in man. Thorax. 1987;42:946-52.

15. Jarjour NN, Calhoun WJ, Kelly EA, Gleich GJ, Schwartz LB, Busse WW. The immediate and late allergic response to segmental bronchopulmonary provocation in asthma. Am J Respir Crit Care Med. 1997;155:1515-21.

16. Bousquet J, Jeffery PK, Busse WW, Johnson M, Vignola AM. Asthma: From bronchoconstriction to airways inflammation and remodeling. Am J Respir Crit Care Med. 2000;161(5):1720-45.

17. Barnes PJ. Immunology of asthma and chronic obstructive pulmonary disease. Nat Rev Immunol. 2008:8:183-92. 2008/02/16 ed.

18. Raemdonck K, de Alba J, Birrell MA, Grace M, Maher SA, Irvin CG, et al. A role for sensory nerves in the late asthmatic response. Thorax. 2012;67:19-25.

19. Shin YS, Takeda K, Gelfand EW. Understanding asthma using animal models. Allergy Asthma Immunol Res. 2009;1:10-8.

20. Stevenson CS, Birrell MA. Moving towards a new generation of animal models for asthma and COPD with improved clinical relevance. Pharmacol Ther. 2011;130:93-105.

21. Shapiro SD. The use of transgenic mice for modeling airways disease. Pulm Pharmacol Ther. 2008;21:699-701.

22. Graham MT, Nadeau KC. Lessons learned from mice and man: mimicking human allergy through mouse models. Clin Immunol. 2014;155:1-16.

23. Holmes AM, Solari R, Holgate ST. Animal models of asthma: value, limitations and opportunities for alternative approaches. Drug Discov Today. 2011;16:659-70.

24. Nabe T, Zindl CL, Jung YW, Stephens R, Sakamoto A, Kohno S, et al. Induction of a late asthmatic response associated with airway inflammation in mice. Eur J Pharmacol. 2005:521:144-55. 2005/09/27 ed.

25. Raemdonck K, Baker K, Dale N, Dubuis E, Shala F, Belvisi MG, Birrell MA. CD4(+) and CD8(+) T cells play a central role in a HDM driven model of allergic asthma. Respir Res. 2016;17:45.
26. Rastrick JM, Stevenson CS, Eltom S, Grace M, Davies M, Kilty I, Evans SM, Pasparakis M, Catley MC, Lawrence T, et al. Cigarette smoke induced airway inflammation is independent of NF-kappaB signalling. Plos One. 2013;8: e54128.

27. Birrell MA, De Alba J, Catley MC, Hardaker E, Wong S, Collins M, Clarke DL, Farrow SN, Willson TM, Collins JL, Belvisi MG. Liver X receptor agonists increase airway reactivity in a model of asthma via increasing airway smooth muscle growth. J Immunol. 2008;181:4265-71.

28. Birrell MA, Wong S, Hardaker EL, Catley MC, Mccluskie K, Collins M, Haj-Yahia S, Belvisi MG. IkappaB kinase-2-independent and -dependent inflammation in airway disease models: relevance of IKK-2 inhibition to the clinic. Mol Pharmacol. 2006;69:1791-800.

29. Birrell MA, Mccluskie K, Wong S, Donnelly LE, Barnes PJ, Belvisi MG. Resveratrol, an extract of red wine, inhibits lipopolysaccharide induced airway neutrophilia and inflammatory mediators through an NF-kappaBindependent mechanism. FASEB J. 2005;19:840-1.

30. Birrell MA, Hardaker E, Wong S, Mccluskie K, Catley M, De Alba J, Newton R, Haj-Yahia S, Pun KT, Watts CJ, et al. Ikappa-B kinase-2 inhibitor blocks inflammation in human airway smooth muscle and a rat model of asthma. Am J Respir Crit Care Med. 2005;172:962-71.

31. Snelgrove RJ, Goulding J, Didierlaurent AM, Lyonga D, Vekaria S, Edwards L, et al. A critical function for CD200 in lung immune homeostasis and the severity of influenza infection. Nat Immunol. 2008;9:1074-83. 2008/07/29 ed.

32. Yagil Z, Hadad Erlich T, Ofir-Birin Y, Tshori S, Kay G, Yekhtin Z, et al. Transcription factor E3, a major regulator of mast cell-mediated allergic response. J Allergy Clin Immunol. 2012;129:1357-66. 2012/03/01 ed.

33. Smit M, Zuidhof AB, Bos SIT, Maarsingh H, Gosens R, Zaagsma J, et al. Bronchoprotection by olodaterol is synergistically enhanced by tiotropium in a Guinea pig model of allergic asthma. J Pharmacol Exp Ther. 2014;348:303-10.

34. Mueller R, Chanez P, Campbell AM, Bousquet J, Heusser C, Bullock GR. Different cytokine patterns in bronchial biopsies in asthma and chronic bronchitis. Respir Med. 1996;90:79-85.

35. Muratov V, Barck C, Bylin G, Källström E, Halldén $G$, van Hage M, et al. Allergen challenge alters intracellular cytokine expression. Scand J Immunol. 2005;62:161-7.

36. Out TA, Wang S-Z, Rudolph K, Bice DE. Local T-cell activation after segmental allergen challenge in the lungs of allergic dogs. Immunology. 2002;105:499-508.

37. Meyts I, Vanoirbeek JA, Hens G, Vanaudenaerde BM, Verbinnen B, Bullens DM, et al. T-cell mediated late increase in bronchial tone after allergen provocation in a murine asthma model. Clin Immunol. 2008;128:248-58. 2008/05/27 ed.

38. Nabe T, Morishita T, Matsuya K, Ikedo A, Fujii M, Mizutani N, et al. Complete dependence on CD4+ cells in late asthmatic response, but limited contribution of the cells to airway remodeling in sensitized mice. J Pharmacol Sci. 2011;116:373-83. 2011/07/23 ed.

39. Ohtomo T, Kaminuma O, Kitamura N, Suko M, Kobayashi N, Mori A. Murine Th clones confer late asthmatic response upon antigen challenge. Int Arch Allergy Immunol. 2009;149:2-6.

40. Watanabe A, Mishima H, Renzi PM, Xu LJ, Hamid Q, Martin JG. Transfer of allergic airway responses with antigen-primed CD4+ but not CD8+ T cells in brown Norway rats. J Clin Invest. 1995;96:1303-10.

41. Haczku A, Mogbel R, Jacobson M, Kay AB, Barnes PJ, Chung KF. T-cells subsets and activation in bronchial mucosa of sensitized Brown-Norway rats after single allergen exposure. Immunology. 1995;85:591-7.

42. Olivenstein R, Renzi PM, Yang JP, Rossi P, Laberge S, Waserman S, et al. Depletion of OX-8 lymphocytes from the blood and airways using monoclonal antibodies enhances the late airway response in rats. J Clin Invest. 1993;92:1477-82.

43. Allakhverdi Z, Lamkhioued B, Olivenstein R, Hamid Q, Renzi PM. CD8 depletion-induced late airway response is characterized by eosinophilia, increased eotaxin, and decreased IFN-gamma expression in rats. Am J Respir Crit Care Med. 2000;162:1123-31. 2000/09/16 ed.

44. Suzuki M, Taha R, Ihaku D, Hamid Q, Martin JG. CD8+ T cells modulate late allergic airway responses in Brown Norway rats. J Immunol. 1999;163:5574-81.

45. Isogai S, Hamid Q, Minshall E, Miyake S, Yoshizawa Y, Taha R, et al. Interferongamma increases IL-12 mRNA expression and attentuates allergic late-onset aimay responses in the Brown Norway rat. Eur Respir J. 2000;16:22-9.

46. Isogai S, Rubin A, Maghni K, Ramos-Barbon D, Taha R, Yoshizawa Y, et al. The effects of CD8 + gammadelta T cells on late allergic airway responses and airway inflammation in rats. J Allergy Clin Immunol. 2003;112:547-55. 
47. Kemeny DM, Noble A, Holmes BJ, Diaz-Sanchez D. Immune regulation: a new role for the CD8+ T cell. Immunol Today. 1994;15:107-10.

48. Li Y, Richards D, Noble A, Kemeny DM. Cytokine production by highly purified human CD8+ T cells. Int Arch Allergy Immunol. 1995;107:354-5.

49. Isogai S, Athiviraham A, Fraser RS, Taha R, Hamid Q, Martin JG. Interferongamma-dependent inhibition of late allergic airway responses and eosinophilia by CD8+ gammadelta T cells. Immunology. 2007;122:230-8.

50. Gajewski TF, Goldwasser E, Fitch FW. Anti-proliferative effect of IFN-gamma in immune regulation. II. IFN-gamma inhibits the proliferation of murine bone marrow cells stimulated with IL-3, IL-4, or granulocyte-macrophage colony-stimulating factor. J Immunol. 1988;141:2635-42.

51. Gajewski TF, Joyce J, Fitch FW. Antiproliferative effect of IFN-gamma in immune regulation. III. Differential selection of $\mathrm{TH} 1$ and $\mathrm{TH} 2$ murine helper T lymphocyte clones using recombinant IL-2 and recombinant IFN-gamma. J Immunol. 1989;143:15-22.

52. Young HA, Hardy KJ. Role of interferon-gamma in immune cell regulation. J Leukoc Biol. 1995;58:373-81.

53. Nakamura T, Lee RK, Nam SY, Podack ER, Bottomly K, Flavell RA. Roles of IL-4 and IFN-gamma in stabilizing the T helper cell type 1 and 2 phenotype. J Immunol. 1997;158:2648-53.

54. Iwamoto I, Nakajima $H$, Endo $H$, Yoshida S. Interferon gamma regulates antigen-induced eosinophil recruitment into the mouse airways by inhibiting the infiltration of CD4+ T cells. J Exp Med. 1993;177:573-6.

55. Isogai S, Jedrzkiewicz S, Taha R, Hamid Q, Martin JG. Resident CD8+ T cells suppress CD4+ T cell-dependent late allergic airway responses. J Allergy Clin Immunol. 2005;115:521-6.

56. Mizutani N, Goshima H, Nabe T, Yoshino S. Establishment and characterization of a murine model for allergic asthma using allergenspecific lgE monoclonal antibody to study pathological roles of lgE. Immunol Lett. 2012;141:235-45.

57. Nabe T, Yamashita K, Miura M, Kawai T, Kohno S. Cysteinyl leukotrienedependent interleukin-5 production leading to eosinophilia during late asthmatic response in guinea-pigs. Clin Exp Allergy. 2002;32:633-40.

58. Peebles RS, Hamilton RG, Lichtenstein LM, Schlosberg M, Liu MC, Proud D, et al. Antigen-specific lgE and IgA antibodies in bronchoalveolar lavage fluid are associated with stronger antigen-induced late phase reactions. Clin Exp Allergy. 2001;31:239-48.

59. Crimi E, Chiaramondia M, Milanese M, Rossi GA, Brusasco V. Increased numbers of mast cells in bronchial mucosa after the late-phase asthmatic response to allergen. Am Rev Respir Dis. 1991;144:1282-6.

60. James A, Gyllfors P, Henriksson E, Dahlen SE, Adner M, Nilsson G, et al. Corticosteroid treatment selectively decreases mast cells in the smooth muscle and epithelium of asthmatic bronchi. Allergy. 2012;67:958-61. 2012/05/16 ed.

61. Cockcroft DW, Murdock KY. Comparative effects of inhaled salbutamol, sodium cromoglycate, and beclomethasone dipropionate on allergeninduced early asthmatic responses, late asthmatic responses, and increased bronchial responsiveness to histamine. J Allergy Clin Immunol. 1987;79:734-40. 1987/05/01 ed.

62. Pepys J, Hargreave FE, Chan M, McCarthy DS. Inhibitory effects of disodium cromoglycate on allergen-inhalation tests. Lancet. 1968;2:134-7. 1968/07/20 ed.

63. Pepys J, Davies RJ, Breslin AB, Hendrick DJ, Hutchcroft BJ. The effects of inhaled beclomethasone dipropionate (Becotide) and sodium cromoglycate on asthmatic reactions to provocation tests. Clin Allergy. 1974;4:13-24. 1974/03/01 ed.

64. Cieslewicz G, Tomkinson A, Adler A, Duez C, Schwarze J, Takeda K, et al. The late, but not early, asthmatic response is dependent on IL-5 and correlates with eosinophil infiltration. J Clin Invest. 1999;104:301-8. 1999/08/03 ed.

65. Busse W, Corren J, Lanier BQ, McAlary M, Fowler-Taylor A, Cioppa GD, et al. Omalizumab, anti-lgE recombinant humanized monoclonal antibody, for the treatment of severe allergic asthma. J Allergy Clin Immunol. 2001;108: 184-90. 2001/08/10 ed.

66. Holgate S, Casale T, Wenzel S, Bousquet J, Deniz Y, Reisner C. The antiinflammatory effects of omalizumab confirm the central role of $\mathrm{lgE}$ in allergic inflammation. J Allergy Clin Immunol. 2005;115:459-65. 2005/03/09 ed.

67. Fahy JV, Fleming HE, Wong HH, Liu JT, Su JQ, Reimann J, et al. The effect of an anti-lgE monoclonal antibody on the early- and late-phase responses to allergen inhalation in asthmatic subjects. Am J Respir Crit Care Med. 1997;155:1828-34. 1997/06/01 ed.

68. Durham SR, Lee TH, Cromwell O, Shaw RJ, Merrett TG, Merrett J, et al. Immunologic studies in allergen-induced late-phase asthmatic reactions. J Allergy Clin Immunol. 1984;74:49-60.
69. Tschopp JM, Sistek D, Schindler C, Leuenberger P, Perruchoud AP, Wüthrich $B$, et al. Current allergic asthma and rhinitis: diagnostic efficiency of three commonly used atopic markers (lgE, skin prick tests, and Phadiatop). Results from 8329 randomized adults from the SAPALDIA Study. Swiss Study on Air Pollution and Lung Diseases in Adults. Allergy. 1998;53:608-13.

70. Scrivener S, Britton J. Immunoglobulin E and allergic disease in Africa. Clin Exp Allergy. 2000;30:304-7.

71. Ali FR, Oldfield WLG, Higashi N, Larché M, Kay AB. Late asthmatic reactions induced by inhalation of allergen-derived T cell peptides. Am J Respir Crit Care Med. 2004;169:20-6.

72. Khan LN, Kon OM, Macfarlane AJ, Meng Q, Ying S, Barnes NC, et al. Attenuation of the allergen-induced late asthmatic reaction by cyclosporin $A$ is associated with inhibition of bronchial eosinophils, interleukin-5, granulocyte macrophage colony-stimulating factor, and eotaxin. Am J Respir Crit Care Med. 2000;162:1377-82

73. Kojima T, Obata K, Mukai K, Sato S, Takai T, Minegishi Y, et al. Mast cells and basophils are selectively activated in vitro and in vivo through CD200R3 in an IgE-independent manner. J Immunol. 2007;179:7093-100.

74. Ohnmacht C, Schwartz C, Panzer M, Schiedewitz I, Naumann R, Voehringer D. Basophils orchestrate chronic allergic dermatitis and protective immunity against helminths. Immunity. 2010;33:364-74.

75. Voehringer D. Protective and pathological roles of mast cells and basophils. Nat Rev Immunol. 2013;13:362-75.

76. Lei Y, Gregory JA, Nilsson GP, Adner M. Insights into mast cell functions in asthma using mouse models. Pulm Pharmacol Ther. 2013;26(5):532-9. 2013/ 04/16 ed.

77. Krug N, Rabe KF. Animal models for human asthma: the perspective of a clinician. Curr Drug Targets. 2008;9:438-42.

78. Andersson CK, Mori M, Bjermer L, Löfdahl C-G, Erjefält JS. Novel site-specific mast cell subpopulations in the human lung. Thorax. 2009;64:297-305.

79. Xing W, Austen KF, Gurish MF, Jones TG. Protease phenotype of constitutive connective tissue and of induced mucosal mast cells in mice is regulated by the tissue. Proc Natl Acad Sci U S A. 2011;108:14210-5.

80. Szelenyi I. Animal models of bronchial asthma. Inflamm Res. 2000;49:639-54.

\section{Submit your next manuscript to BioMed Central and we will help you at every step:}

- We accept pre-submission inquiries

- Our selector tool helps you to find the most relevant journal

- We provide round the clock customer support

- Convenient online submission

- Thorough peer review

- Inclusion in PubMed and all major indexing services

- Maximum visibility for your research

Submit your manuscript at www.biomedcentral.com/submit

) Biomed Central 